\title{
Synthesis of Chiral Allylic Esters by Using the New Recyclable Chiral Heterogeneous Oxazoline-Based Catalysts
}

\author{
Saadi Samadi*, Akram Ashouri, and Mojgan Samadi
}

Laboratory of Asymmetric Synthesis, Department of Chemistry, Faculty of Science, University of Kurdistan, Sanandaj 66177-15175, Iran. Phone: (+9887) 33624133; Email: s.samadi@uok.ac.ir.

Supporting Information

\begin{tabular}{|c|c|c|c|}
\hline Page & List of contents & Page & List of contents \\
\hline $\mathrm{S} 1$ & Title, author's name, address & S23 & Figure S17: ${ }^{1} \mathrm{HNMR}$ of $7 \mathrm{~b}$ \\
\hline S2-S6 & Experimental section & S24 & Figure S18: ${ }^{13} \mathrm{CNMR}$ of $7 \mathrm{~b}$ \\
\hline S7 & Figure S1: ${ }^{1} \mathrm{HNMR}$ of $2 \mathrm{a}$ & S25 & Figure S19: ${ }^{1} \mathrm{HNMR}$ of $8 \mathrm{a}$ \\
\hline $\mathrm{S} 8$ & Figure S2: ${ }^{13} \mathrm{CNMR}$ of $2 \mathrm{a}$ & S26 & Figure S20: ${ }^{13} \mathrm{CNMR}$ of $8 \mathrm{a}$ \\
\hline S9 & Figure S3: ${ }^{1} \mathrm{HNMR}$ of $2 \mathrm{~b}$ & S27 & Figure S21: ${ }^{1} \mathrm{HNMR}$ of $8 \mathrm{~b}$ \\
\hline S10 & Figure $\mathrm{S} 4:{ }^{13} \mathrm{CNMR}$ of $2 \mathrm{~b}$ & S28 & Figure S22: ${ }^{13} \mathrm{CNMR}$ of $8 \mathrm{~b}$ \\
\hline $\mathrm{S} 11$ & Figure S5: ${ }^{1} \mathrm{HNMR}$ of $2 \mathrm{c}$ & S29 & Figure S23: ${ }^{1} \mathrm{HNMR}$ of $8 \mathrm{f}$ \\
\hline S12 & Figure S6: ${ }^{13} \mathrm{CNMR}$ of $2 \mathrm{c}$ & S30 & Figure S24: ${ }^{13} \mathrm{CNMR}$ of $8 \mathrm{f}$ \\
\hline S13 & Figure S7: ${ }^{1} \mathrm{HNMR}$ of $2 \mathrm{~d}$ & S31 & Figure S25: ${ }^{1} \mathrm{HNMR}$ of $9 \mathrm{~b}$ \\
\hline S14 & Figure S8: ${ }^{13} \mathrm{CNMR}$ of $2 \mathrm{~d}$ & S32 & Figure S26: ${ }^{13} \mathrm{CNMR}$ of $9 \mathrm{~b}$ \\
\hline S15 & Figure S9: ${ }^{1} \mathrm{HNMR}$ of $3 \mathrm{a}$ & S33 & Figure S27: ${ }^{1} \mathrm{H}$ NMR of $10 \mathrm{~b}$ \\
\hline S16 & Figure S10: ${ }^{13} \mathrm{CNMR}$ of $3 \mathrm{a}$ & S34 & Figure S28: ${ }^{13} \mathrm{C}$ NMR of $10 \mathrm{~b}$ \\
\hline S17 & Figure S11: ${ }^{1} \mathrm{HNMR}$ of $3 \mathrm{~b}$ & S35 & Figure S29: ${ }^{1} \mathrm{HNMR}$ of $11 \mathrm{~b}$ \\
\hline S18 & Figure $\mathrm{S} 12:{ }^{13} \mathrm{CNMR}$ of $3 \mathrm{~b}$ & S36 & Figure S30: ${ }^{13} \mathrm{C}$ NMR of $11 \mathrm{~b}$ \\
\hline S19 & Figure S13: ${ }^{1} \mathrm{HNMR}$ of $3 \mathrm{c}$ & S37 & Figure S31: Chromatogram of 8a \\
\hline $\mathrm{S} 20$ & Figure S14: ${ }^{13} \mathrm{CNMR}$ of $3 \mathrm{c}$ & S38 & Figure S32: Chromatogram of $8 \mathrm{~b}$ \\
\hline $\mathrm{S} 21$ & Figure S15: ${ }^{1} \mathrm{HNMR}$ of $3 \mathrm{~d}$ & S39 & References \\
\hline $\mathrm{S} 22$ & Figure S16: ${ }^{13} \mathrm{CNMR}$ of $3 \mathrm{~d}$ & & \\
\hline
\end{tabular}




\section{Experimental}

\section{Materials and characterization methods}

Melting points were measured on an Electrothermal 9100 apparatus and were uncorrected. Fourier transform infrared (FT-IR) spectrum of SBA-15 was monitored by Bruker. Vector 22 spectrometer with potassium bromide plate. ${ }^{1} \mathrm{H}$ and ${ }^{13} \mathrm{C}$ NMR spectra were recorded on a BRUKER DRX-300 AVANCE spectrometer at 300.13, 400.22 MHz and $75 \mathrm{MHz}, 100$ $\mathrm{MHz}$ in $\mathrm{CDCl}_{3}$ using TMS $(\delta=0.0 \mathrm{ppm})$ an internal standard. X-ray diffraction (XRD) was performed on a Bruker D8 Advance powder diffractometer with Ni filtered CuKa radiation $(\lambda=1.54056 \AA)$. The morphology of nanoporous was investigated by a scanning electron microscope (FESEM-TESCAN MIRA3). TGA-DTA analysis was carried out from 0 to $800^{\circ} \mathrm{C}$ at a heating rate of $10{ }^{\circ} \mathrm{C} / \mathrm{min}$ using a STA PT-1000 LINSEIS. Optical rotations were measured with a Perkin-Elmer 341 polarimeter at $589 \mathrm{~nm}$. Enantiomeric excess (ee) of the products were determined by HPLC on chiralpak AD and/or chiralcel OD-H and/or Nucleocel Alpha S columns. All reactions were performed under an atmosphere of dry and oxygen-free nitrogen. All reagents and starting materials were purchased from Aldrich, Merck, Fluka and Sigma. Olefins were distilled from calcium hydride before use. All solvents for the reactions were reagent grade and were dried and distilled immediately before use as follows: acetonitrile and acetone from $\mathrm{P}_{2} \mathrm{O}_{5}$, methylene chloride from calcium hydride, methanol from $\mathrm{Mg}$ and $\mathrm{I}_{2}$, toluene and tetrahydrofuran from sodium and benzophenone. Column chromatography was performed using silica gel $60(0.063-0.2 \mathrm{~mm})$ eluting with ethyl acetate and $n$-hexane. Thinlayer chromatography (TLC) was performed using silica gel $60 \mathrm{~F}_{256}$ plates with visualization by UV.

\section{A typical procedure for the synthesis of chiral amino alcohols $2 a-d$ :}

To an oven-dried 3-neck $250 \mathrm{~mL}$ round-bottom flask equipped with reflux condenser, sodium borohydride (40.0 mmol, $1.51 \mathrm{~g})$ and $20 \mathrm{~mL}$ of dried tetrahydrofuran were added. After 15 minutes, $(S)$-phenylalanine $\mathbf{1 b}(16.6 \mathrm{mmol}, 2.75 \mathrm{~g})$ was added in one portion to the stirring solution. Then the resulting mixture was cooled to $0{ }^{\circ} \mathrm{C}$, and $\mathrm{I}_{2}(16.5 \mathrm{mmol}, 4.27 \mathrm{~g})$ in $10 \mathrm{~mL}$ of tetrahydrofuran was added dropwise by the addition funnel over 30 minutes. After fading 
away the brownish color of solution, the mixture was warmed to room temperature and then the white cloudy solution refluxed for 48 hours. After cooling to room temperature, to the cloudy white suspension with fast stirring, $10 \mathrm{~mL}$ of $\mathrm{CH}_{3} \mathrm{OH}$ was added dropwise by addition funnel and gas evolution observed. The resulting solution was concentrated, and the obtained residue dissolved in $10 \mathrm{~mL}$ of $\mathrm{KOH}(20 \%)$ and then stirred for 4 hours at room temperature. The obtained solution was extracted with $\mathrm{CH}_{2} \mathrm{Cl}_{2}(3 \times 20 \mathrm{~mL})$, the organic layer washed with brine, and then the aqueous layer back extracted with $\mathrm{CH}_{2} \mathrm{Cl}_{2}(20 \mathrm{~mL})$. The combined organic layers were dried over anhydrous $\mathrm{MgSO}_{4}$ and concentrated. The white solid $\mathbf{2 b}$ was afforded in 95\% yield. Other chiral products $\mathbf{2 a}, \mathbf{2 c}$, and $\mathbf{2 d}$ were also synthesized from the corresponding amino acids in the similar procedure in a good yields up to $98 \%{ }^{1}$ (Figures S1-8).

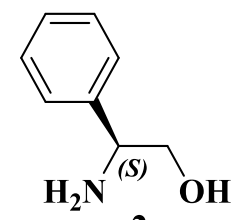

$\mathbf{2 a}$

(S)-2-amino-2-phenylethan-1-ol (2a): Mp: 75-78 ${ }^{\circ}$.; FT-IR $\left(\mathrm{KBr}, \mathrm{cm}^{-1}\right): 3274,3062,2922$, 1598, 1489, 1045.; ${ }^{1} \mathrm{H}$ NMR (400 MHz, $\left.\mathrm{CDCl}_{3}\right): \delta_{\mathrm{H}}(\mathrm{ppm})=2.53(1 \mathrm{H}$, brs, $(\mathrm{OH})), 2.75(2 \mathrm{H}$, brs, $\left.\left(\mathrm{NH}_{2}\right)\right), 3.57\left(1 \mathrm{H}, \mathrm{t}, J=9.6 \mathrm{~Hz}, \mathrm{CH}_{2}\right), 3.69\left(1 \mathrm{H}, \mathrm{t}, J=8.6 \mathrm{~Hz}, \mathrm{CH}_{2}\right), 4.04-4.05(1 \mathrm{H}, \mathrm{m}, \mathrm{CH})$, 7.30-7.37 (5H, m, Ar).; $\left.{ }^{13} \mathrm{C} \mathrm{NMR} \mathrm{(100} \mathrm{MHz,} \mathrm{CDCl}_{3}\right): \delta_{\mathrm{C}}(\mathrm{ppm})=57.4,67.8,126.6,127.4$, $127.5,128.6,128.8,142.3 . ;[\alpha]^{25} \mathrm{D}=+30.5^{\circ}(c=0.6, \mathrm{HCl}(1 \mathrm{M}))$.

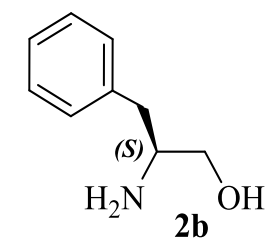

(S)-2-amino-3-phenylpropan-1-ol (2b): $\mathrm{Mp}$ : 90-92 ${ }^{\circ} \mathrm{C}$.; ${ }^{1} \mathrm{H} \mathrm{NMR}\left(400 \mathrm{MHz}, \mathrm{CDCl}_{3}\right): \delta_{\mathrm{H}}$ (ppm) $=2.19\left(3 \mathrm{H}\right.$, brs, $\left.\left(\mathrm{NH}_{2}, \mathrm{OH}\right)\right), 2.57\left(1 \mathrm{H}, \mathrm{dd}, J=12.8,9.0 \mathrm{~Hz}, \mathrm{CH}_{2}\right), 2.81(1 \mathrm{H}, \mathrm{dd}, J=12.0,8.6$ $\left.\mathrm{Hz}, \mathrm{CH}_{2}\right), 3.16\left(1 \mathrm{H}, \mathrm{brs},{ }^{*} \mathrm{CH}\right), 3.44\left(1 \mathrm{H}, \mathrm{d}, J=7.6 \mathrm{~Hz}, \mathrm{H}_{2} \mathrm{C}-\mathrm{OH}\right), 3.67\left(1 \mathrm{H}, \mathrm{d}, J=6.8 \mathrm{~Hz}, \mathrm{H}_{2} \mathrm{C}-\right.$ 
$\mathrm{OH}), 7.21-7.35$ (5H, m, Ar).; ${ }^{13} \mathrm{C} \mathrm{NMR}\left(100 \mathrm{MHz}, \mathrm{CDCl}_{3}\right): \delta_{\mathrm{C}}(\mathrm{ppm})=40.8,54.2,66.3,126.4$, 128.6, 129.2, 138.6; $[\alpha]^{25} \mathrm{D}=-10.7^{\circ}(c=0.4, \mathrm{HCl}(1 \mathrm{M}))$.

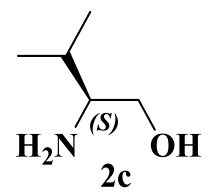

(S)-2-amino-3-methylbutan-1-ol (2c): ${ }^{1} \mathrm{H}$ NMR (400 MHz, $\left.\mathrm{CDCl}_{3}\right): \delta_{\mathrm{H}}(\mathrm{ppm})=0.92(6 \mathrm{H}, \mathrm{d}$, $\left.J=6.8 \mathrm{~Hz}, \mathrm{CH}_{3}\right), 1.67-1.69(1 \mathrm{H}, \mathrm{m}, \mathrm{CH}), 2.66-2.73\left(1 \mathrm{H}, \mathrm{m},{ }^{*} \mathrm{CH}\right), 3.41-3.42\left(1 \mathrm{H}, \mathrm{m},-\mathrm{CH}_{2}-\right.$ $\mathrm{OH}), 3.59-3.62\left(1 \mathrm{H}, \mathrm{m}, \mathrm{H}_{2} \mathrm{C}-\mathrm{OH}\right) .4 .12\left(2 \mathrm{H}\right.$, brs, $\left.\left(\mathrm{NH}_{2}\right)\right)$; ${ }^{13} \mathrm{C} \mathrm{NMR}\left(100 \mathrm{MHz}, \mathrm{CDCl}_{3}\right): \delta_{\mathrm{C}}$ $(\mathrm{ppm})=19.8,31.9,56.6,64.7 . ;[\alpha]^{25} \mathrm{D}=+3.3^{\circ}(c=0.6, \mathrm{EtOH})$.

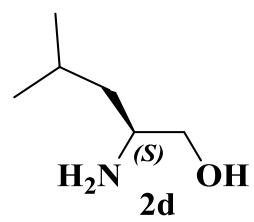

(S)-2-amino-4-methylpentan-1-ol (2d): $\mathrm{Mp}: 69-73^{\circ} \mathrm{C} . ;{ }^{1} \mathrm{H} \mathrm{NMR}\left(400 \mathrm{MHz}, \mathrm{CDCl}_{3}\right): \delta_{\mathrm{H}}(\mathrm{ppm})$ $=0.94\left(6 \mathrm{H}, \mathrm{d}, J=6.8 \mathrm{~Hz}, \mathrm{CH}_{3}\right), 1.24\left(2 \mathrm{H}, \mathrm{brs}, \mathrm{CH}_{2}\right), 1.67-1.75(1 \mathrm{H}, \mathrm{m}, \mathrm{CH}), 2.84(2 \mathrm{H}, \mathrm{brs}$ $\left.\left(\mathrm{NH}_{2}\right)\right), 2.97\left(1 \mathrm{H}\right.$, brs, $\left.{ }^{*} \mathrm{CH}\right), 3.29\left(1 \mathrm{H}, \mathrm{t}, J=9.0 \mathrm{~Hz}, \mathrm{H}_{2} \mathrm{C}-\mathrm{OH}\right), 3.62\left(1 \mathrm{H}, \mathrm{d}, J=8.8 \mathrm{~Hz}, \mathrm{H}_{2} \mathrm{C}-\right.$ $\mathrm{OH}) . ;{ }^{13} \mathrm{C} \mathrm{NMR}\left(100 \mathrm{MHz}, \mathrm{CDCl}_{3}\right): \delta_{\mathrm{C}}(\mathrm{ppm})=22.2,23.3,24.7,43.5,50.7,66.9 . ;[\alpha]^{25} \mathrm{D}=+$ $1.3^{\circ}(c=0.5, \mathrm{EtOH})$.

\section{A typical procedure for the synthesis of Mesoporous silica SBA-15}

Mesoporous silica SBA-15 was synthesized according to the described method in the literature $^{2,3}$. In a round bottom flask $(250 \mathrm{~mL}), 6.0 \mathrm{~g}$ of Pluronic P123 $\left(\mathrm{EO}_{20} \mathrm{PO}_{70} \mathrm{EO}_{20}\right)$ as a surfactant was dissolved in deionized water $(137 \mathrm{~mL})$ and $30 \mathrm{~mL}$ of $\mathrm{HCl}(37 \%)$ at room temperature. After complete copolymer dissolution (0.5-1 hour), $13.7 \mathrm{~g}$ of tetraethyl orthosilicate (TEOS) in deionized water $(50 \mathrm{~mL})$ was added, and stirred vigorously at $40{ }^{\circ} \mathrm{C}$ for 30 minutes. Then the resulting mixture was transferred into a stainless steel jacketed Teflon vessel and heated at $100^{\circ} \mathrm{C}$ for 48 hours. After cooling to room temperature, the solid product was separated from the mixture of reaction by filtration and then washed by deionized water until $\mathrm{pH}=7-8$ was achieved. Finally the obtained powder was dried at $60{ }^{\circ} \mathrm{C}$, and then calcined 
at $550{ }^{\circ} \mathrm{C}$ for 5 hours. The mesoporous structure of SBA- 15 was characterized by FT-IR, XRD, SEM and BET-BJH techniques.

\section{A typical procedure for the synthesis of functionalized SBA-15 (CI-SBA-15)}

Functionalization of SBA-15 was carried out as reported in the literature ${ }^{2,34}$. Briefly, $1.0 \mathrm{~g}$ of SBA-15 in dried toluene $(30 \mathrm{~mL})$ dispersed and, then 3-chloropropyltrimethoxysilane (CPTMS) (4.2 mmol, $0.91 \mathrm{~mL})$ was added. After refluxing the mixture of reaction under nitrogen atmosphere for 24 hours, the modified nonoporous was collected by filtration and washed thoroughly with $\mathrm{CH}_{2} \mathrm{Cl}_{2} / \mathrm{CH}_{3} \mathrm{OH}$. Then the obtained powder was soxhleted for 24 hours with $\mathrm{CH}_{2} \mathrm{Cl}_{2} / \mathrm{CH}_{3} \mathrm{OH}$ (1:1) to remove unreacted 3-chloropropyltriethoxysilane. Finally the functionalized SBA-15 was separated as a white solid and dried at room temperature. The synthesis of functionalized SBA-15 (Cl-SBA-15) was proved by FT-IR, TGA, XRD, SEM and BET-BJH techniques.

\section{A typical procedure for the Synthesis of benzoyl chloride derivatives 6a-g:}

To a round bottom flask under the nitrogen atmosphere, $o$-iodo-benzoic acids $\mathbf{5 b}$ (1.5 mmol, $0.37 \mathrm{~g})$ and dried methylene chloride $(5 \mathrm{~mL})$ were added. After cooling to $0{ }^{\circ} \mathrm{C}$, oxalyl chloride ( $3 \mathrm{mmol}, 0.31 \mathrm{~mL})$ and dimethylformamide $(30 \mu \mathrm{L})$ were slowly added. The mixture was warmed up to room temperature and stirred for 8 hours (Scheme 1). After completion of the reaction, the solvent was removed on a rotary evaporator to provide the $o$-iodo-benzoyl chloride $\mathbf{6 b}$ (0.4 g, quantitative). Other benzoyl chlorides derivatives $6 \mathbf{a}$ and $\mathbf{6 c - g}$ were also prepared from the corresponding benzoic acids in the similar procedure in good yields up to $99 \% \%^{4-8}$.

\section{A typical procedure for the Synthesis of tert-butyl benzoperoxoate derivatives 7a-g:}

In a $50 \mathrm{~mL}$ round bottom flask under the nitrogen atmosphere, $o$-iodo-benzoyl chloride 6b (1.5 mmol, $0.4 \mathrm{~g})$ was dissolved in dried methylene chloride ( $3 \mathrm{~mL})$. After cooling to -20 ${ }^{\circ} \mathrm{C}$, pyridine $(1.7 \mathrm{mmol}, 0.28 \mathrm{~mL})$ and tert-butyl hydroperoxide $(1.7 \mathrm{mmol}, 0.12 \mathrm{~mL})$ were slowly added and stirred for 4.5 hours at $-20{ }^{\circ} \mathrm{C}$ (Scheme 1). After consumption of $o$-iodobenzoyl chloride, the reaction solution was diluted with $\mathrm{CH}_{2} \mathrm{Cl}_{2}(40 \mathrm{~mL})$ and washed with the saturated $\mathrm{NaHCO}_{3}$ in the workup. The organic layer was evaporated and the obtained residue was purified by silica gel column chromatography ( $n$-hexane: EtOAc; 95:5) to afford the tertbutyl-o-iodo benzoperoxoates $\mathbf{7 b}$ (98\% yield). Other tert-butyl benzoperoxoate derivatives $\mathbf{7 a}$ 
and 7c-g were also prepared from the corresponding benzoyl chlorides derivatives in the similar procedure in good yields up to $96 \%{ }^{4-8}$ (Figures S17-18).

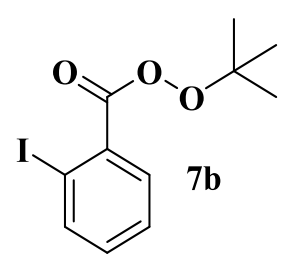

Tert-butyl-2-iodobenzoperoxoate (7b): Mp: 47-49 ${ }^{\circ} \mathrm{C}$.; FT-IR $\left(\mathrm{KBr}, \mathrm{cm}^{-1}\right): 2926,1758,466$; ${ }^{1} \mathrm{HNMR}\left(300 \mathrm{MHz}_{\mathrm{CDCl}}\right): \delta_{\mathrm{H}}(\mathrm{ppm})=1.43\left(9 \mathrm{H}, \mathrm{s}, \mathrm{CH}_{3}\right), 7.20(1 \mathrm{H}, \mathrm{t}, J=7.6 \mathrm{~Hz}, \mathrm{Ar}), 7.42$ $(1 \mathrm{H}, \mathrm{t}, J=7.5 \mathrm{~Hz}, \mathrm{Ar}), 7.59(1 \mathrm{H}, \mathrm{d}, J=7.7 \mathrm{~Hz}, \mathrm{Ar}), 7.97(1 \mathrm{H}, \mathrm{d}, J=7.9 \mathrm{~Hz}, \mathrm{Ar}) . ;{ }^{13} \mathrm{CNMR}(75$ $\left.\mathrm{MHz}, \mathrm{CDCl}_{3}\right): \delta_{\mathrm{C}}(\mathrm{ppm})=26.2,84.3,93.3,127.9,130.3,133.0,134.3,141.9,165.2 . ; \mathrm{m} / \mathrm{z}(\%):$ 320 (0.2, M), 248 (58), 194 (5), 122 (100), 74 (75).

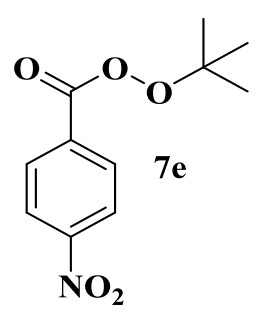

Tert-butyl-4-nitrobenzoperoxoate (7e): Mp: 76-78 ${ }^{\circ} \mathrm{C}\left(\right.$ lit. $\left.75-78{ }^{\circ} \mathrm{C}^{2,9}\right) ;{ }^{1} \mathrm{HNMR}(300 \mathrm{MHz}$, $\left.\mathrm{CDCl}_{3}\right): \delta_{\mathrm{H}}(\mathrm{ppm})=8.14-8.35(4 \mathrm{H}, \mathrm{m}, \mathrm{Ar}), 1.45\left(9 \mathrm{H}, \mathrm{s}, \mathrm{CH}_{3}\right) ;{ }^{13} \mathrm{CNMR}\left(75 \mathrm{MHz}, \mathrm{CDCl}_{3}\right): \delta \mathrm{C}$ $(\mathrm{ppm})=162.5,150.7,133.2,130.3,123.8,84.7,26.2$. 


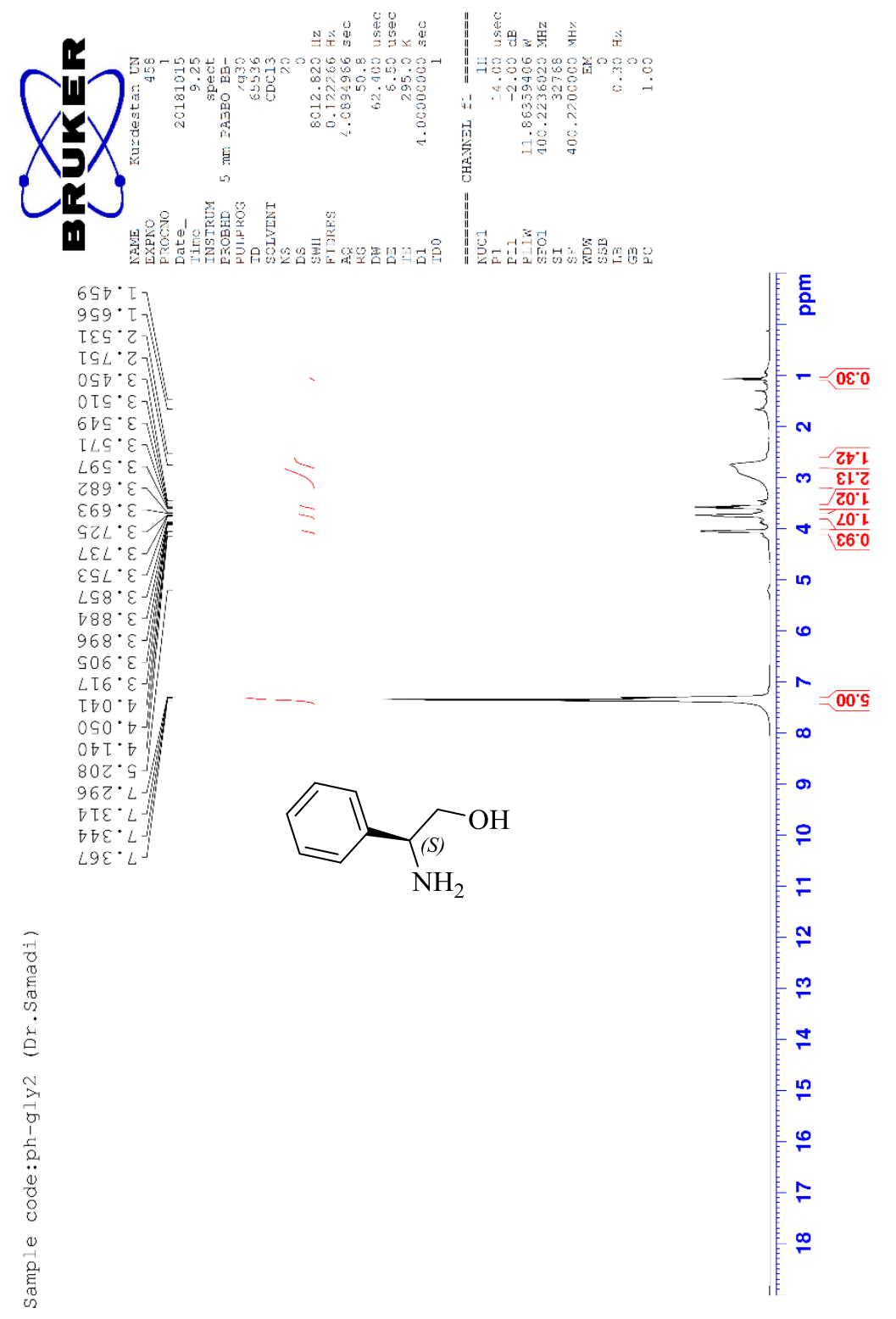

Figure S1: ${ }^{1} \mathrm{H}$ NMR of $\mathbf{2 a}$ 


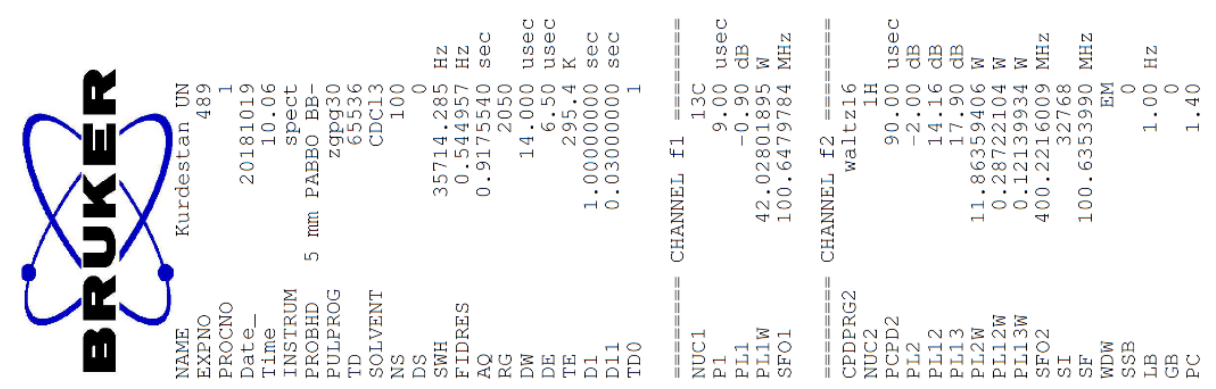

$z 0 \cdot 2 z-$
$92 \cdot 5 z=$

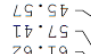

$\left.\begin{array}{l}29 \cdot 79 \\ 68.29 \\ 59.69\end{array}\right]$

$\angle \varepsilon \cdot \varepsilon 9$
$\varsigma 9 \cdot 99$

I8. 29

$78.92-$

9 [. $2 L J$

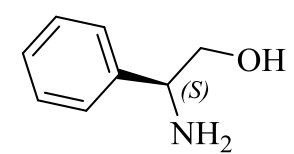

오

$\left.2 \mathrm{Z}^{2} \cdot \mathrm{LZT}\right]$

$9 \varepsilon^{\circ} \cdot \operatorname{LZT}-$

$G S \cdot L Z T-$
$\square D$

$79.82 \mathrm{I}$

56. L L

욤

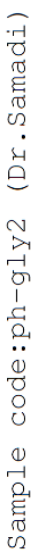

จั่

유

Figure S2: ${ }^{13} \mathrm{CNMR}$ of $\mathbf{2 a}$ 

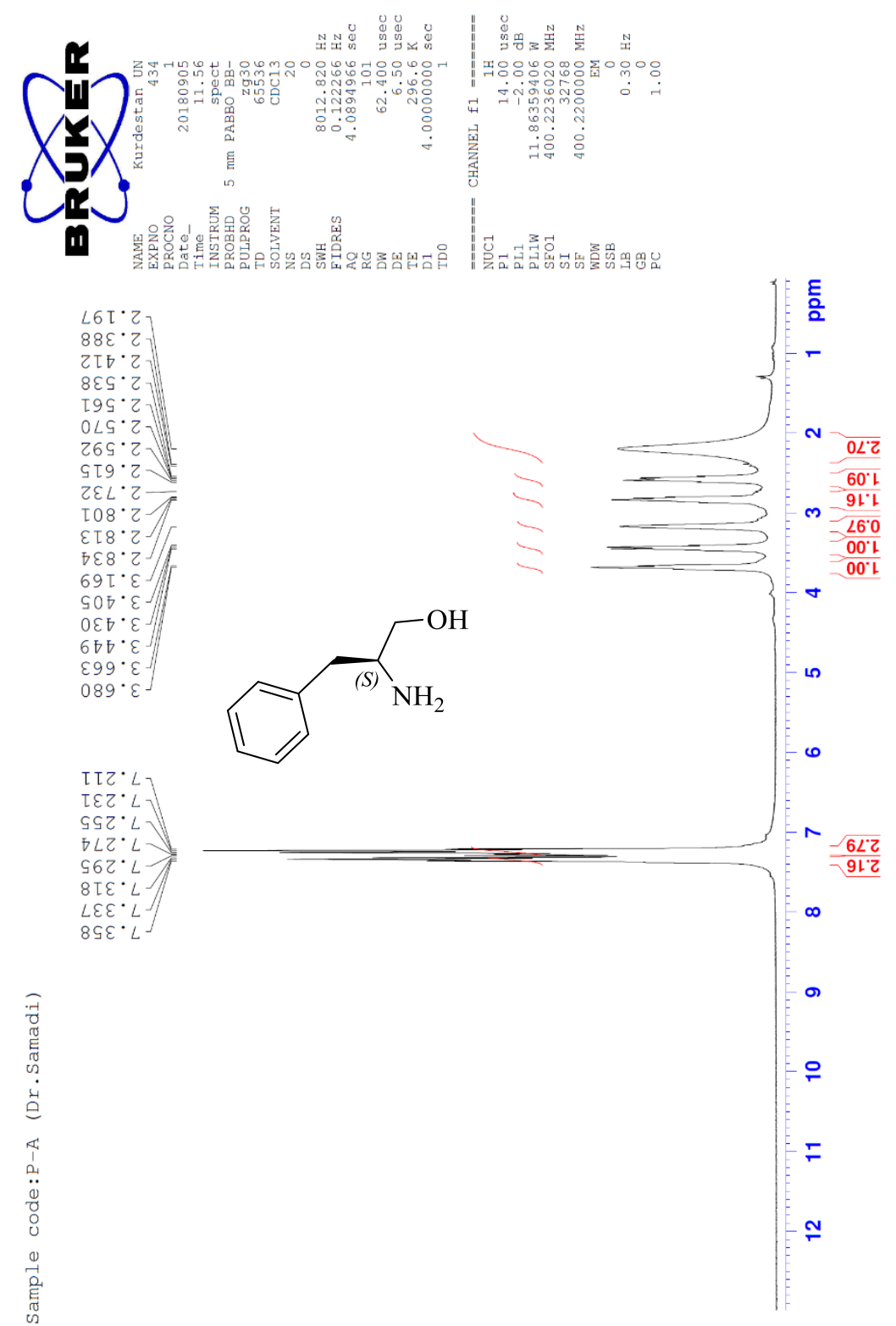

Figure S3: ${ }^{1} \mathrm{H}$ NMR of $\mathbf{2 b}$ 

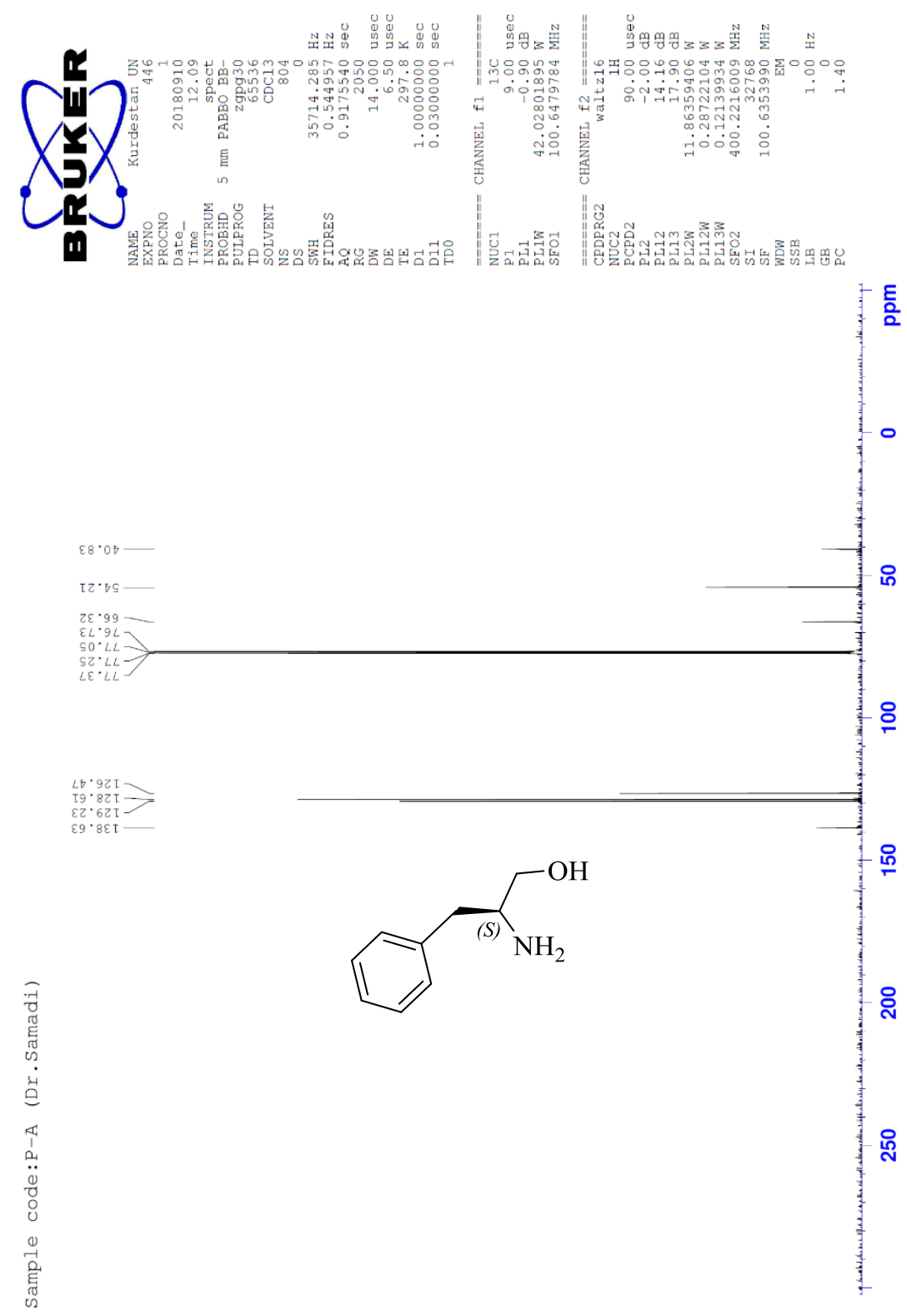

Figure S4: ${ }^{13} \mathrm{CNMR}$ of $\mathbf{2 b}$ 

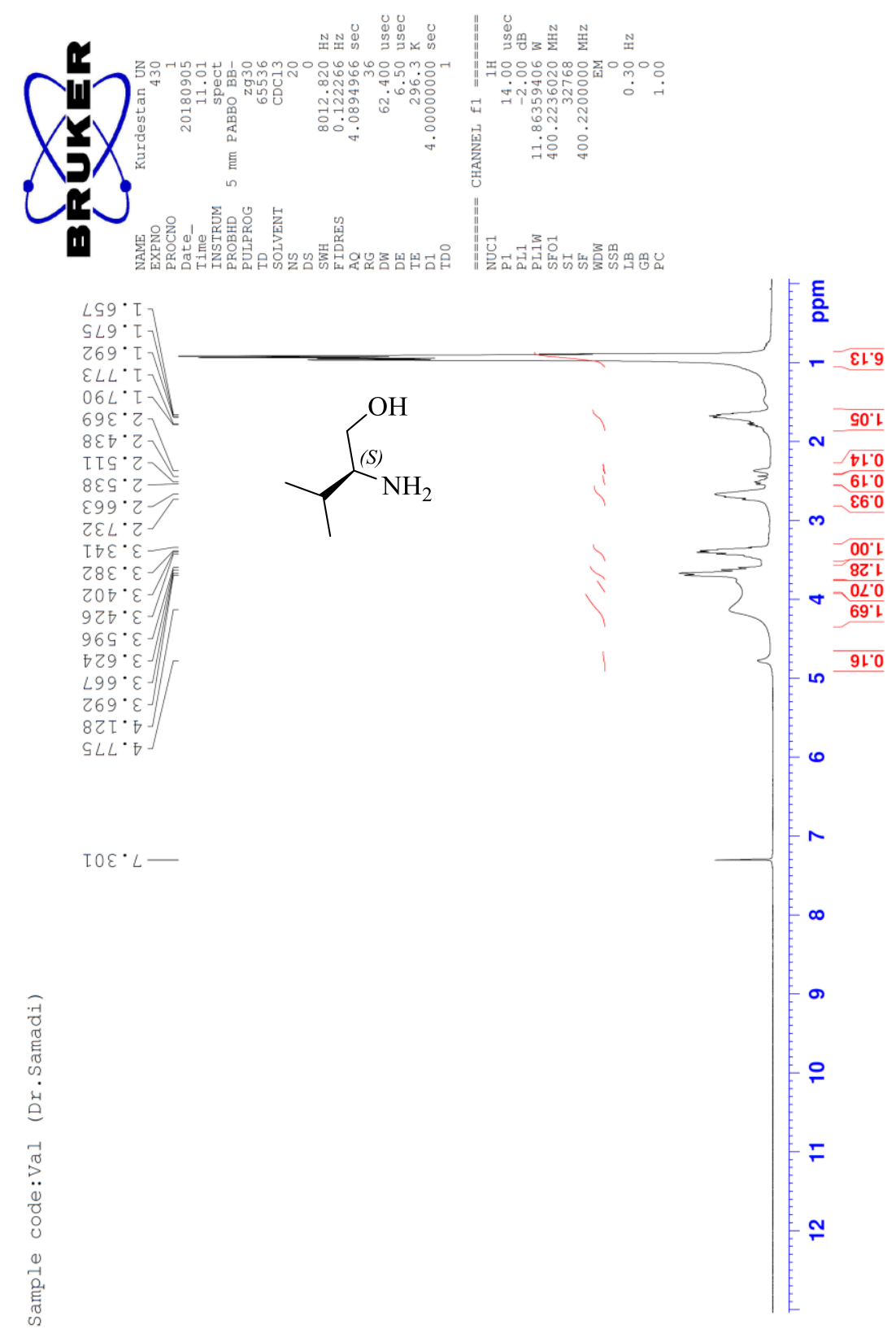

Figure S5: ${ }^{1} \mathrm{H}$ NMR of $2 \mathrm{c}$ 

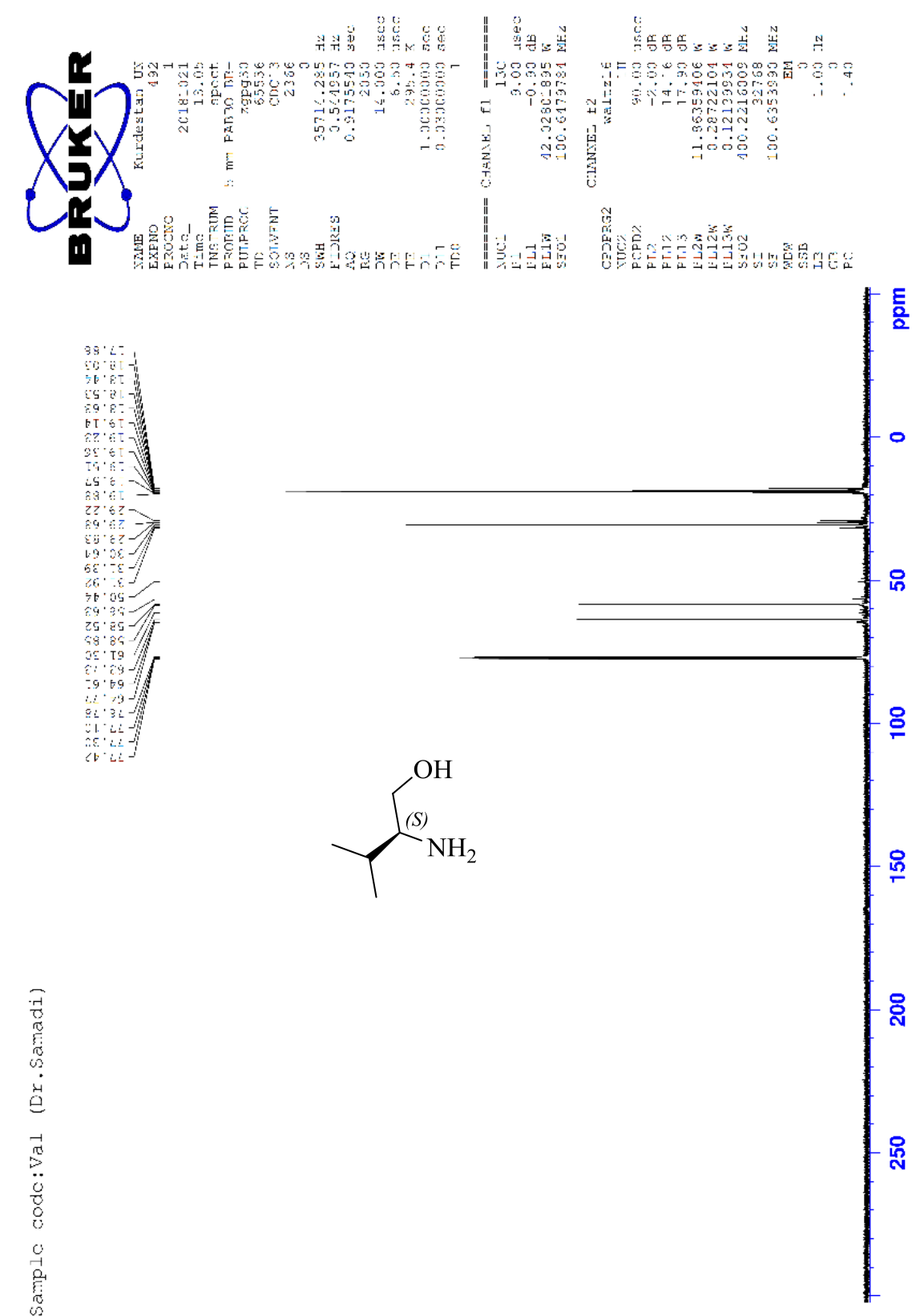

Figure S6: ${ }^{13} \mathrm{CNMR}$ of $2 \mathrm{c}$ 


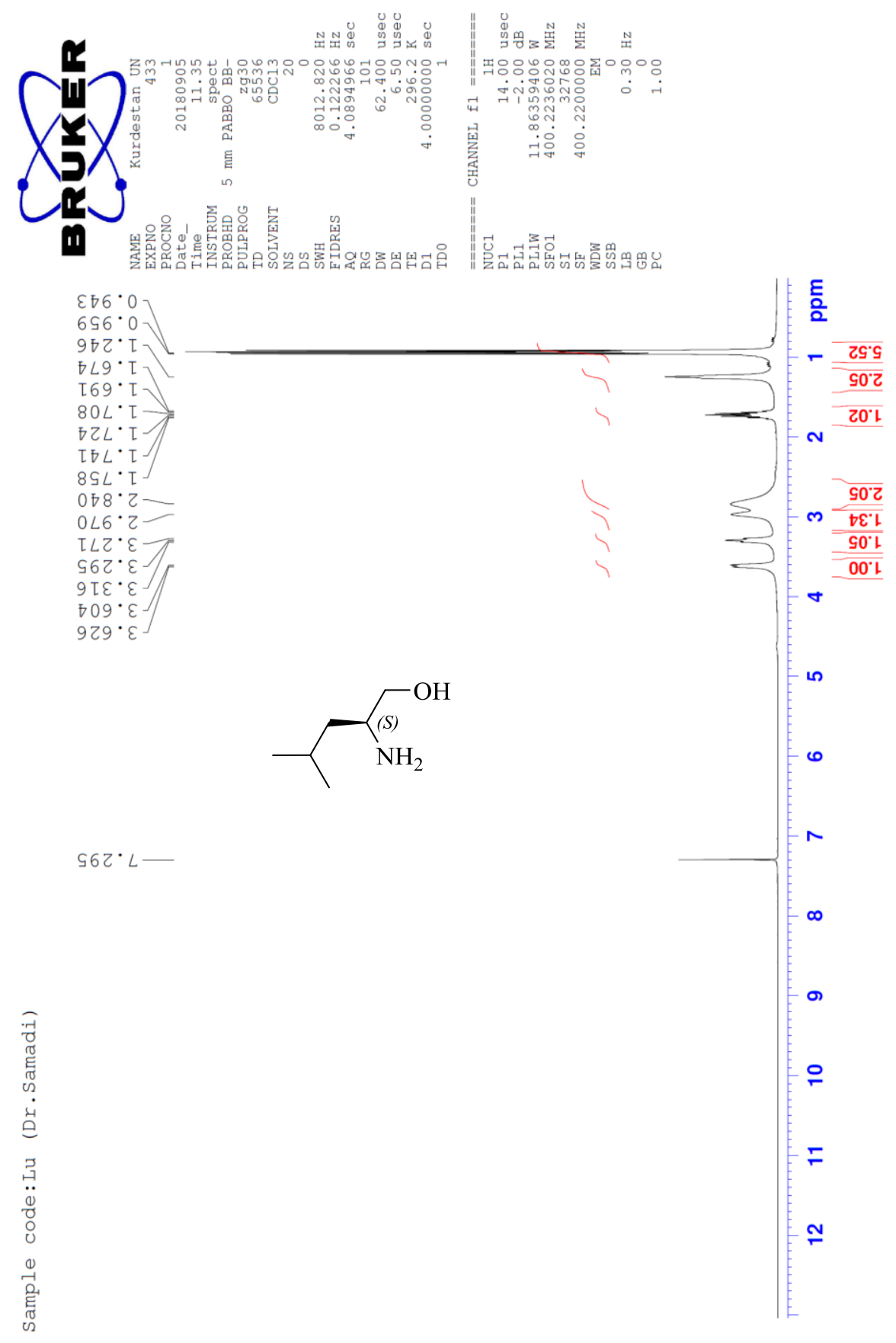

Figure S7: ${ }^{1} \mathrm{H}$ NMR of $\mathbf{2 d}$ 

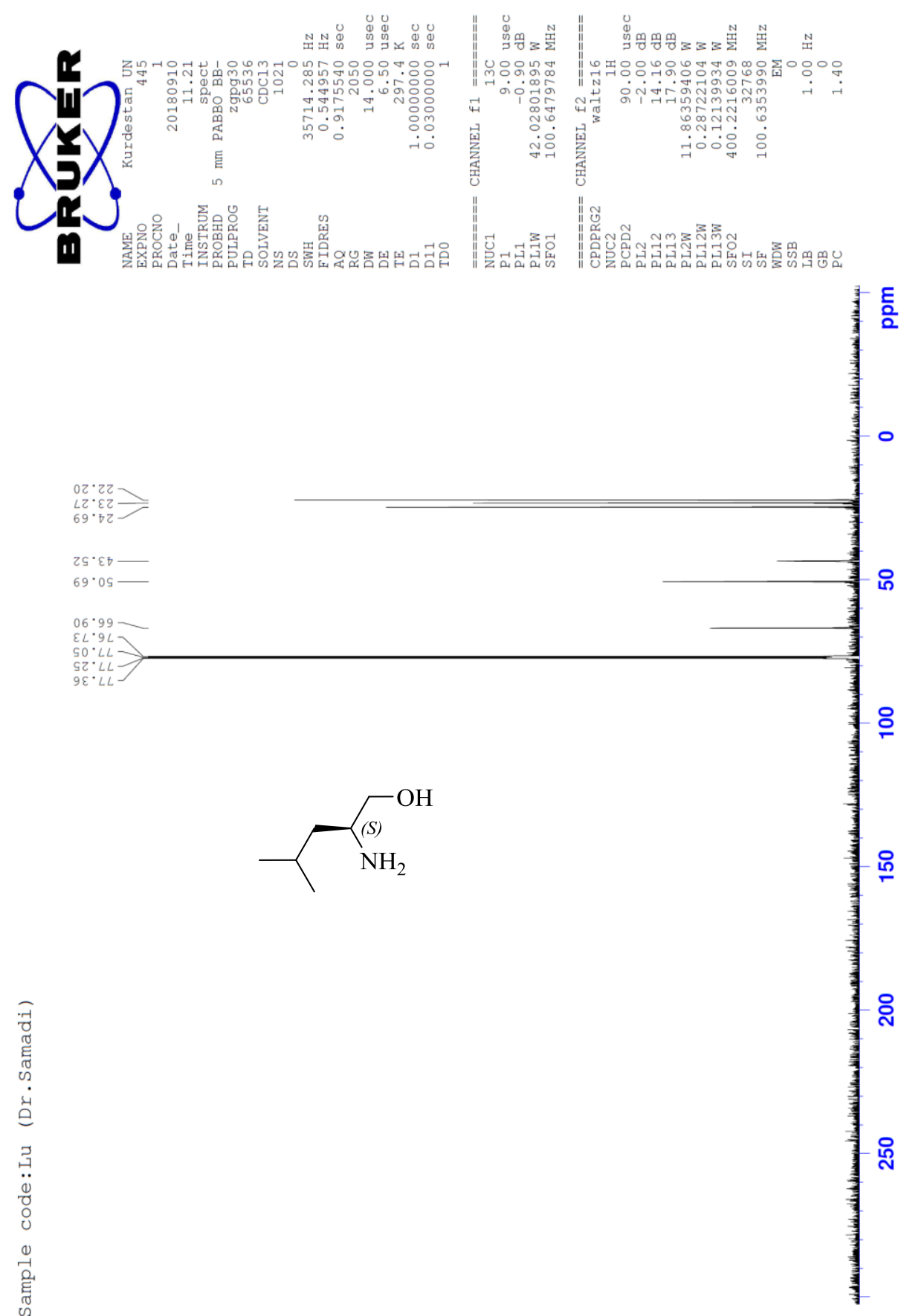

Figure S8: ${ }^{13} \mathrm{CNMR}$ of $\mathbf{2 d}$ 


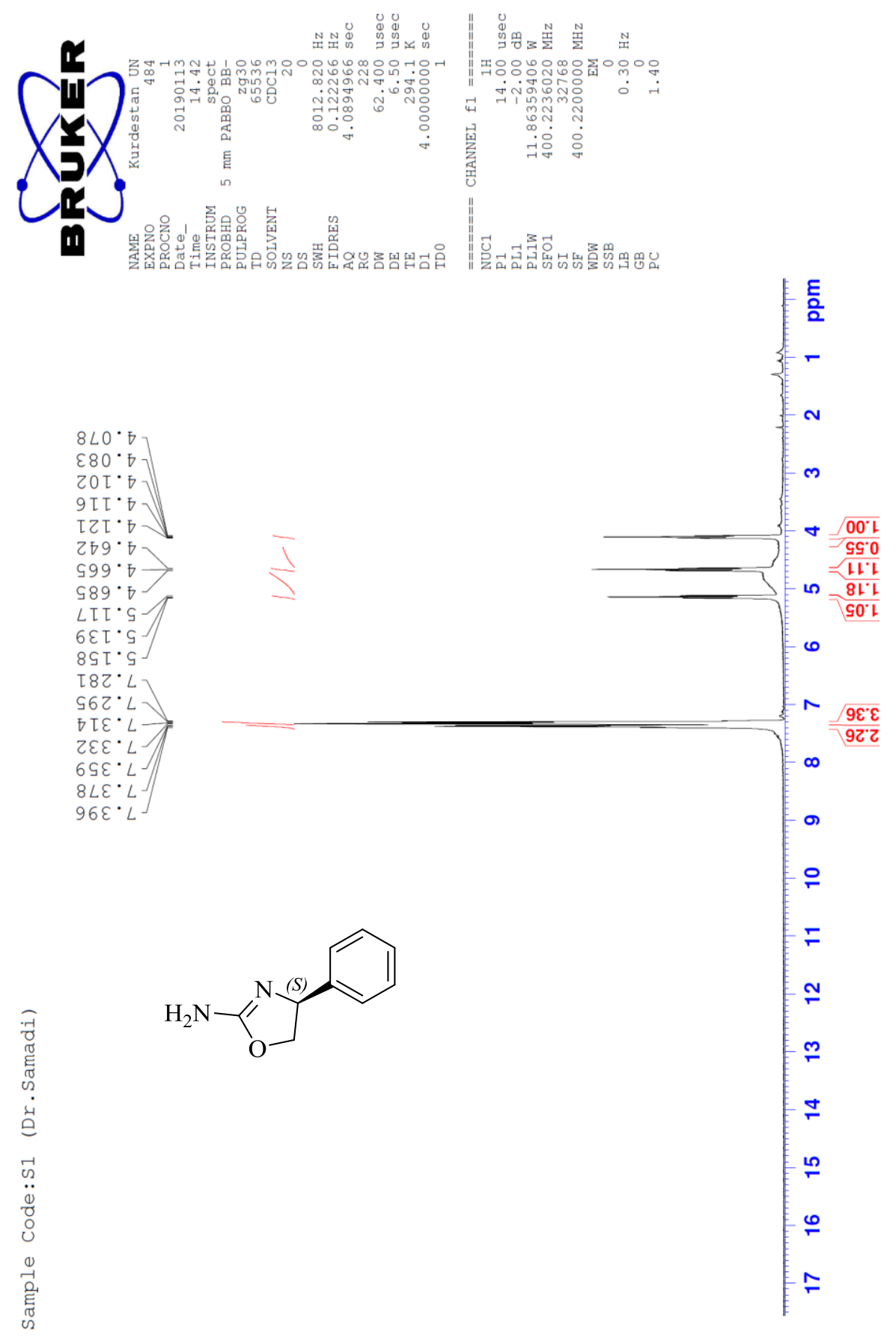

Figure S9: ${ }^{1} \mathrm{H}$ NMR of $\mathbf{3 a}$ 

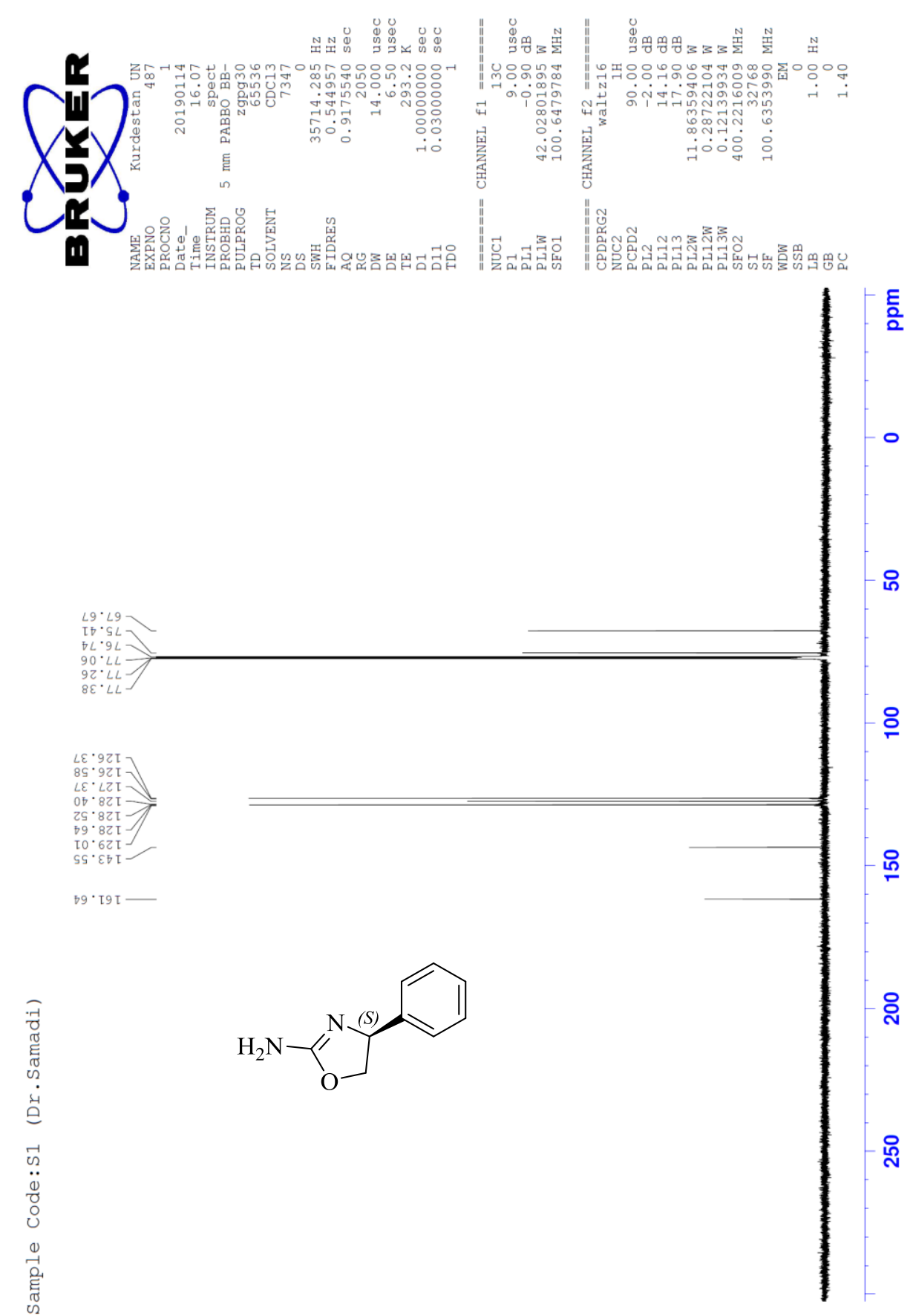

Figure S10: ${ }^{13} \mathrm{CNMR}$ of $\mathbf{3 a}$ 


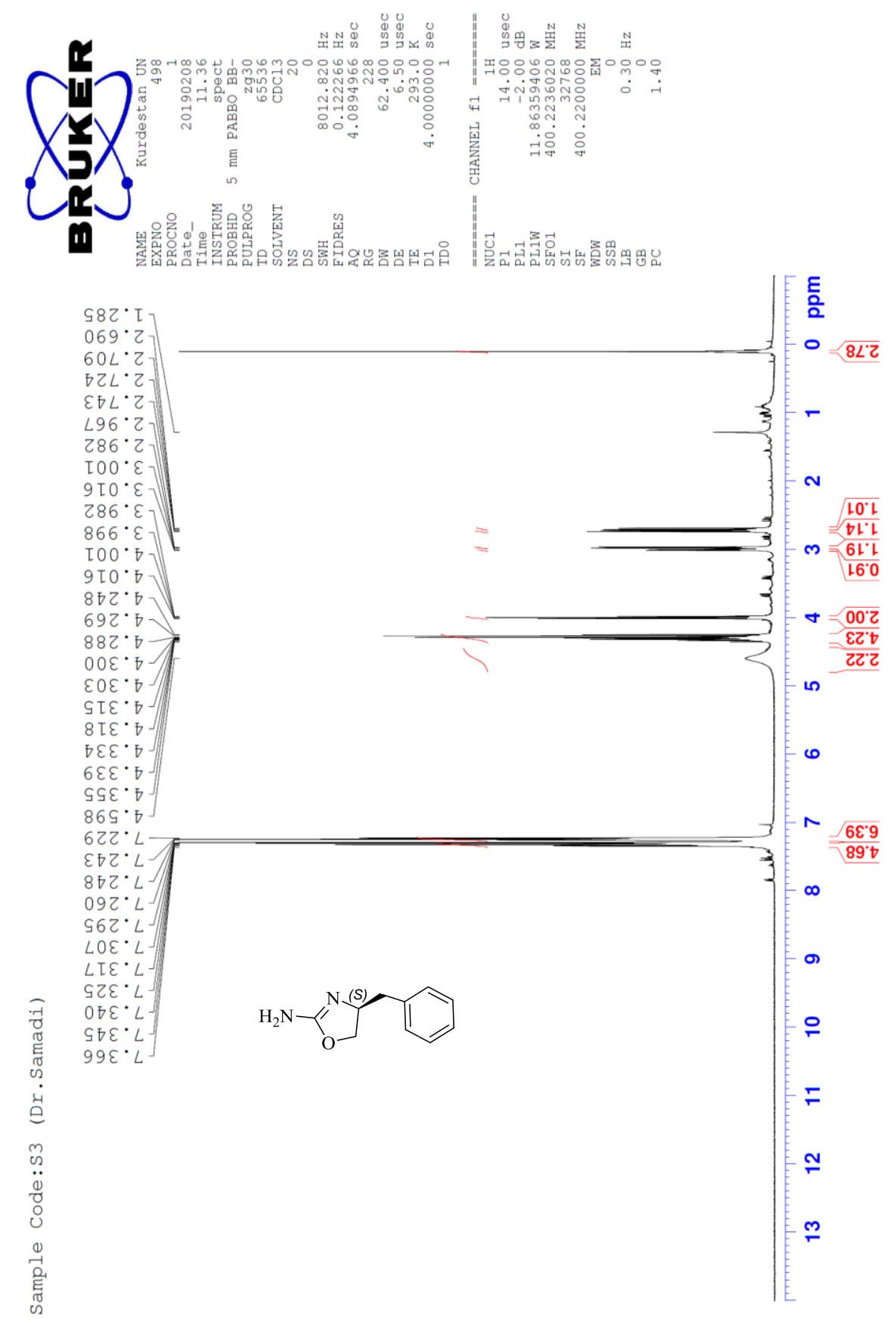

Figure S11: ${ }^{1} \mathrm{H}$ NMR of $\mathbf{3 b}$ 

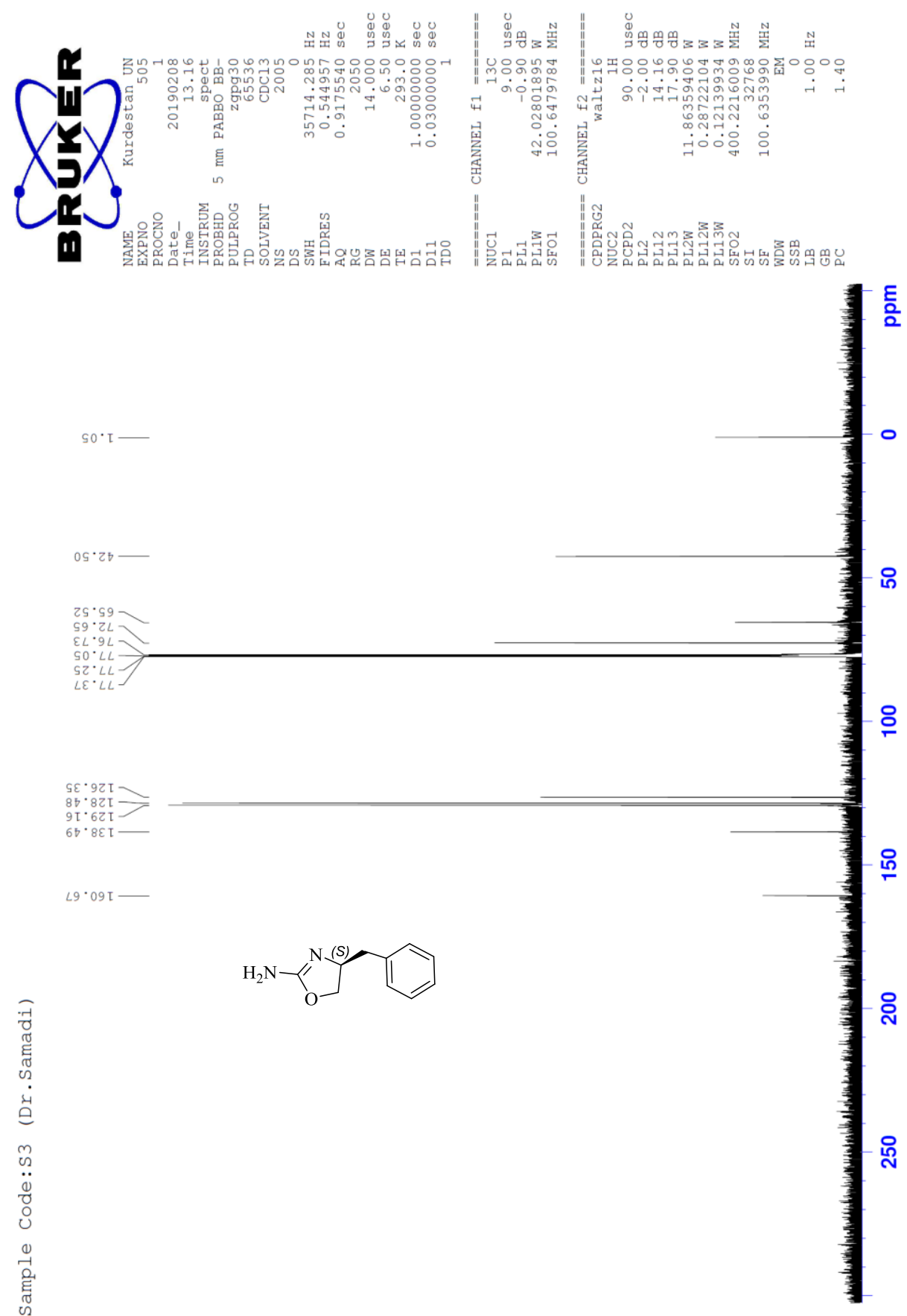

Figure S12: ${ }^{13} \mathrm{CNMR}$ of $\mathbf{3 b}$ 

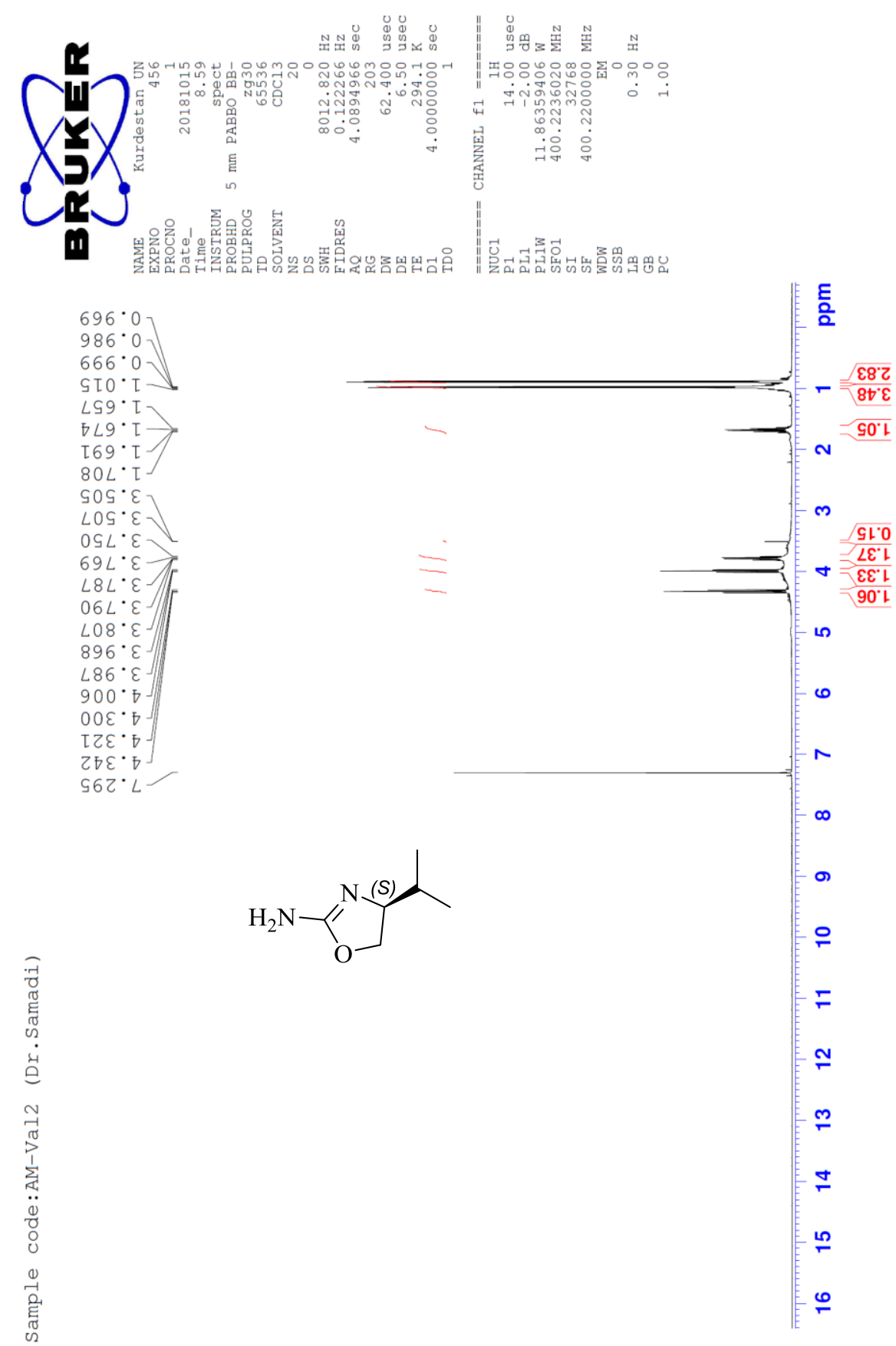

Figure S13: ${ }^{1} \mathrm{H}$ NMR of $3 \mathrm{c}$ 

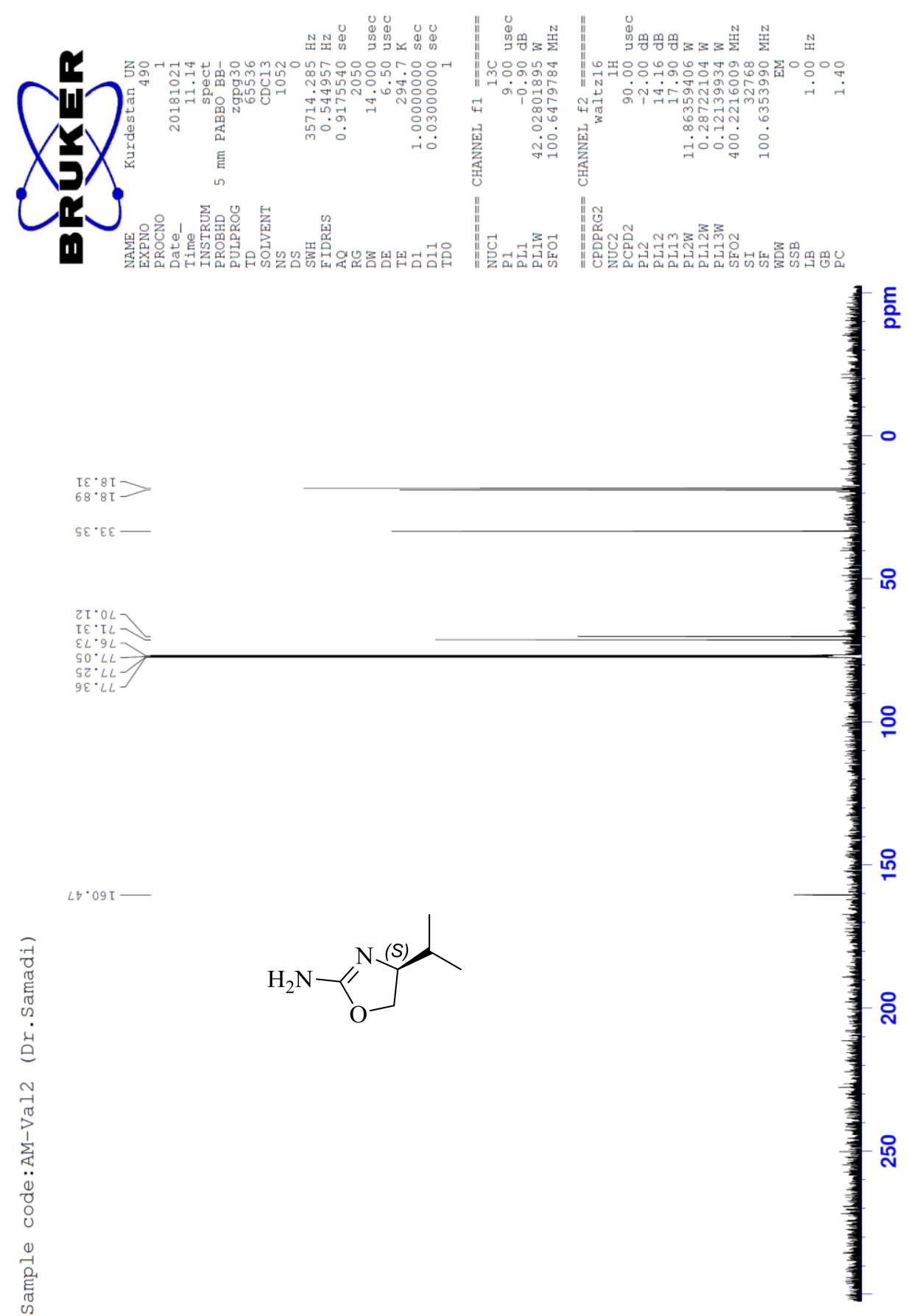

Figure S14: ${ }^{13} \mathrm{CNMR}$ of $\mathbf{3 c}$ 


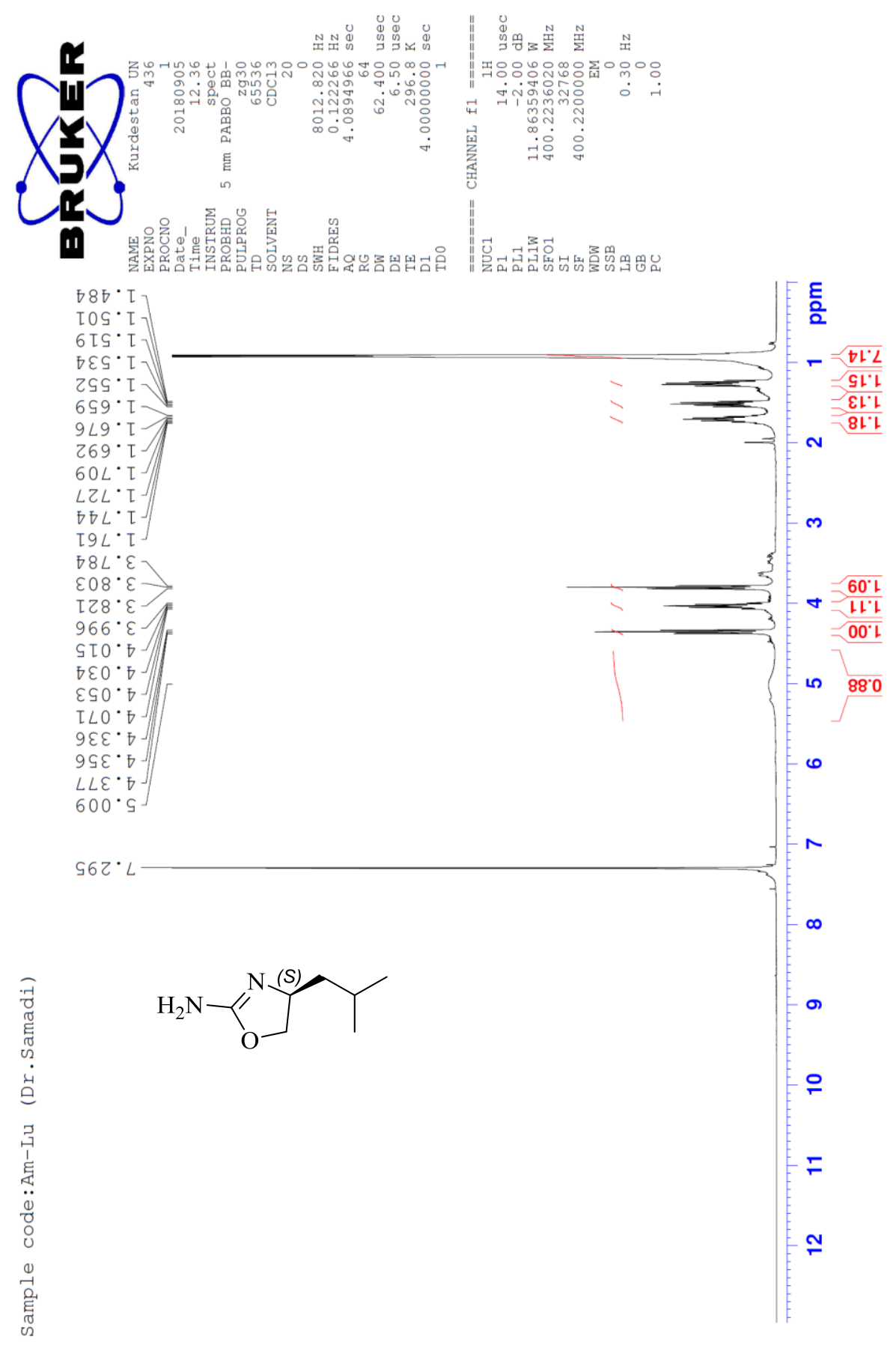

Figure S15: ${ }^{1} \mathrm{H}$ NMR of 3d 

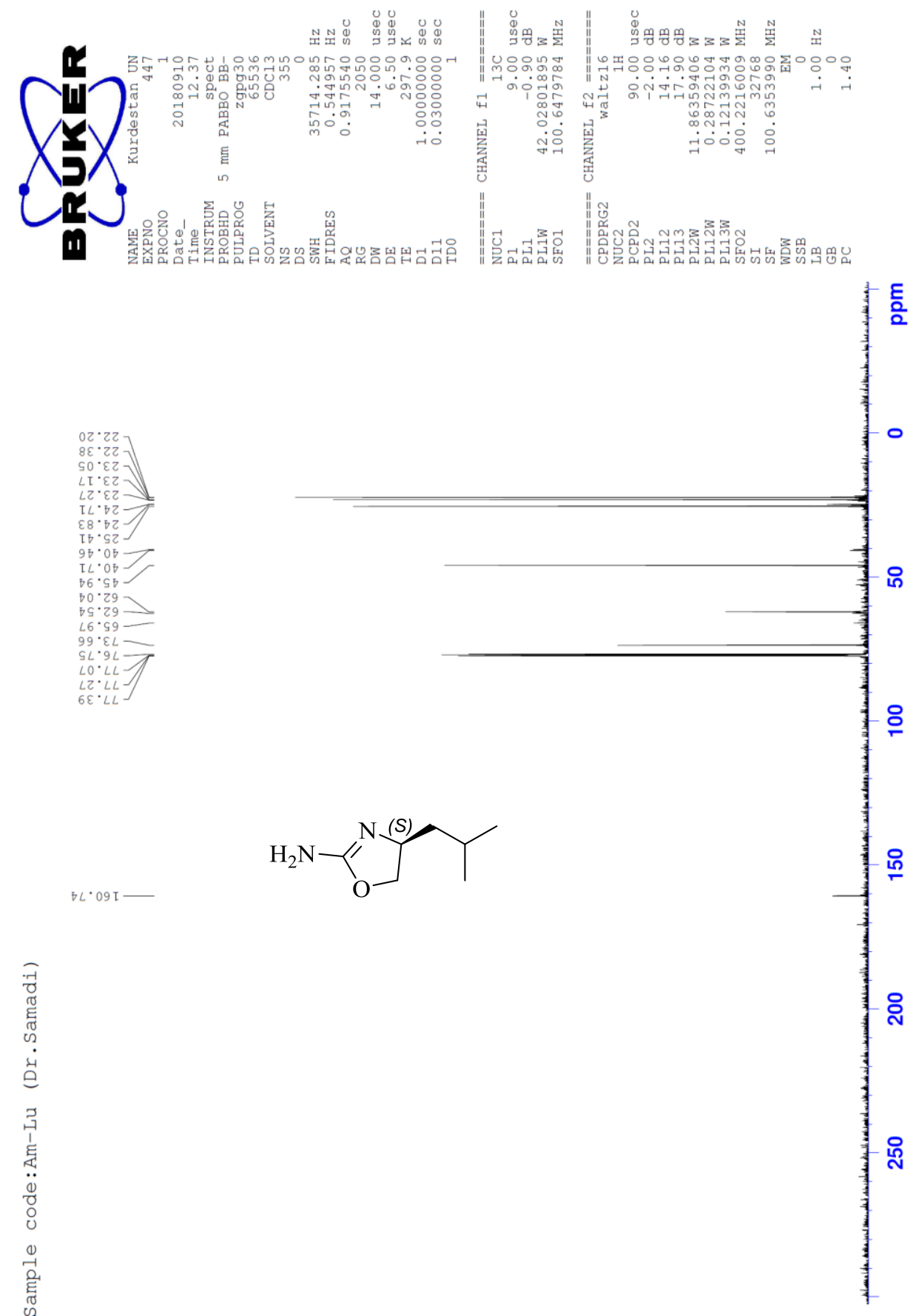

Figure S16: ${ }^{13} \mathrm{CNMR}$ of 3d 

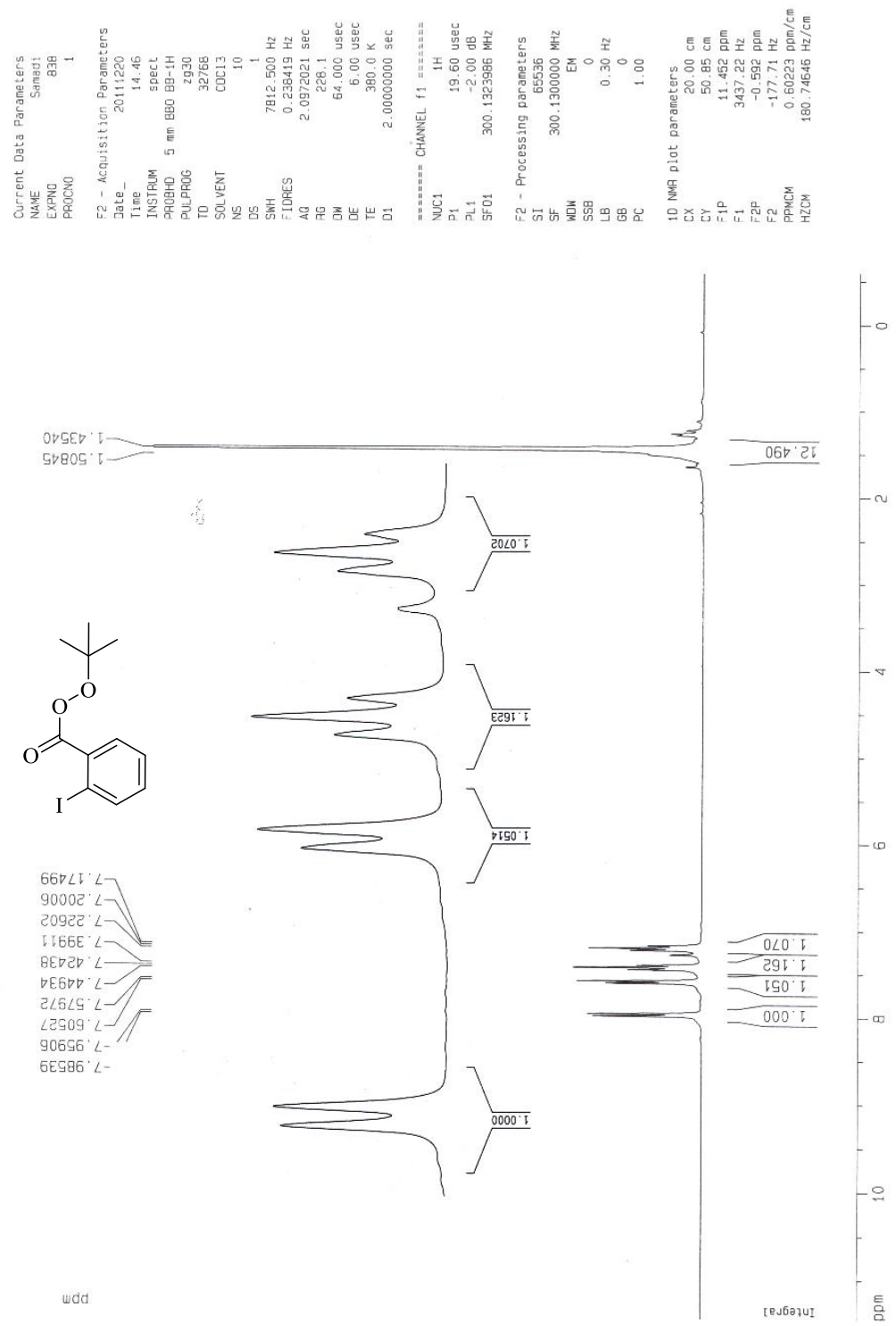

Figure S17: ${ }^{1} \mathrm{H}$ NMR of $\mathbf{7 b}$ 

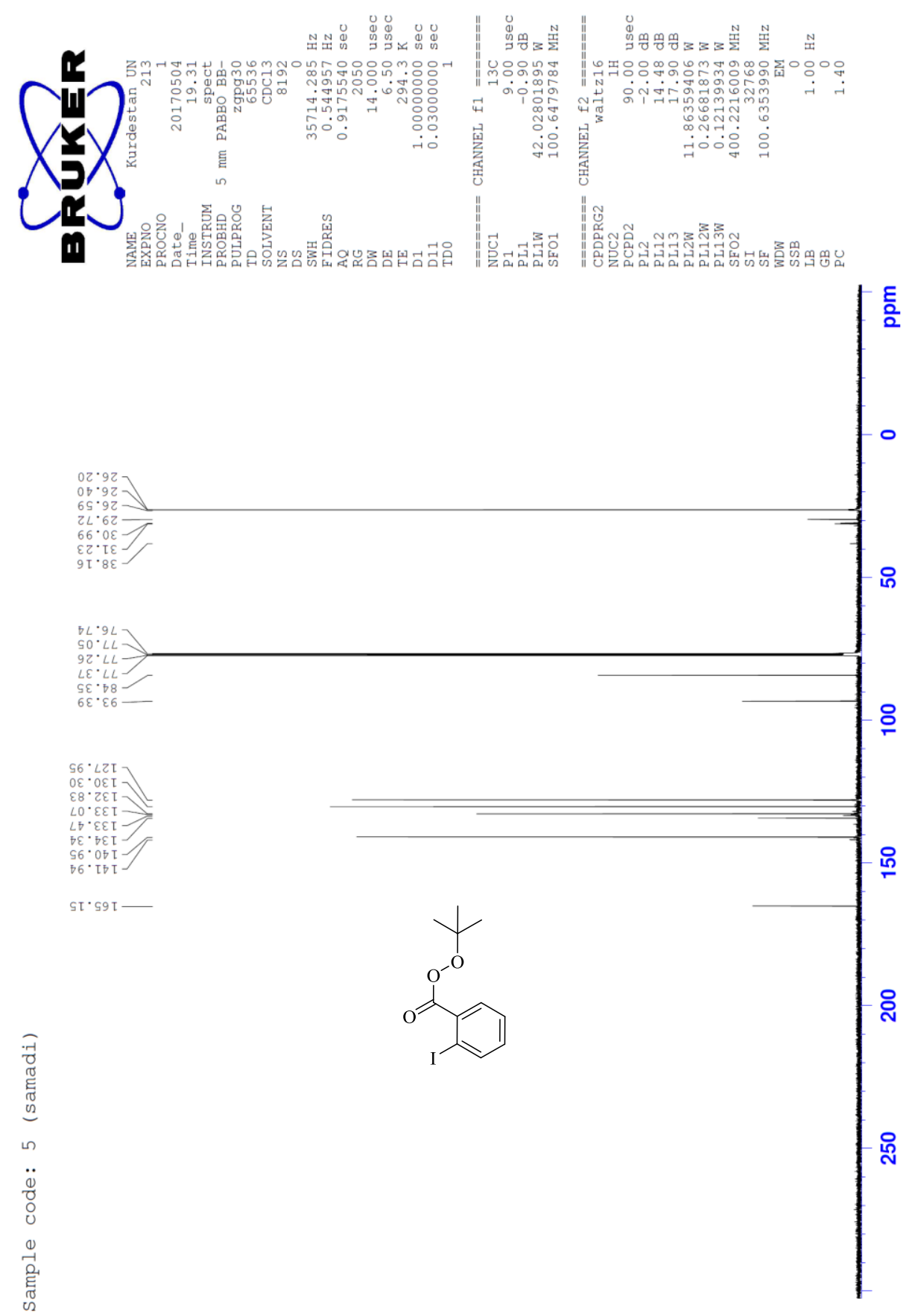

Figure S18: ${ }^{13} \mathrm{CNMR}$ of $\mathbf{7 b}$ 


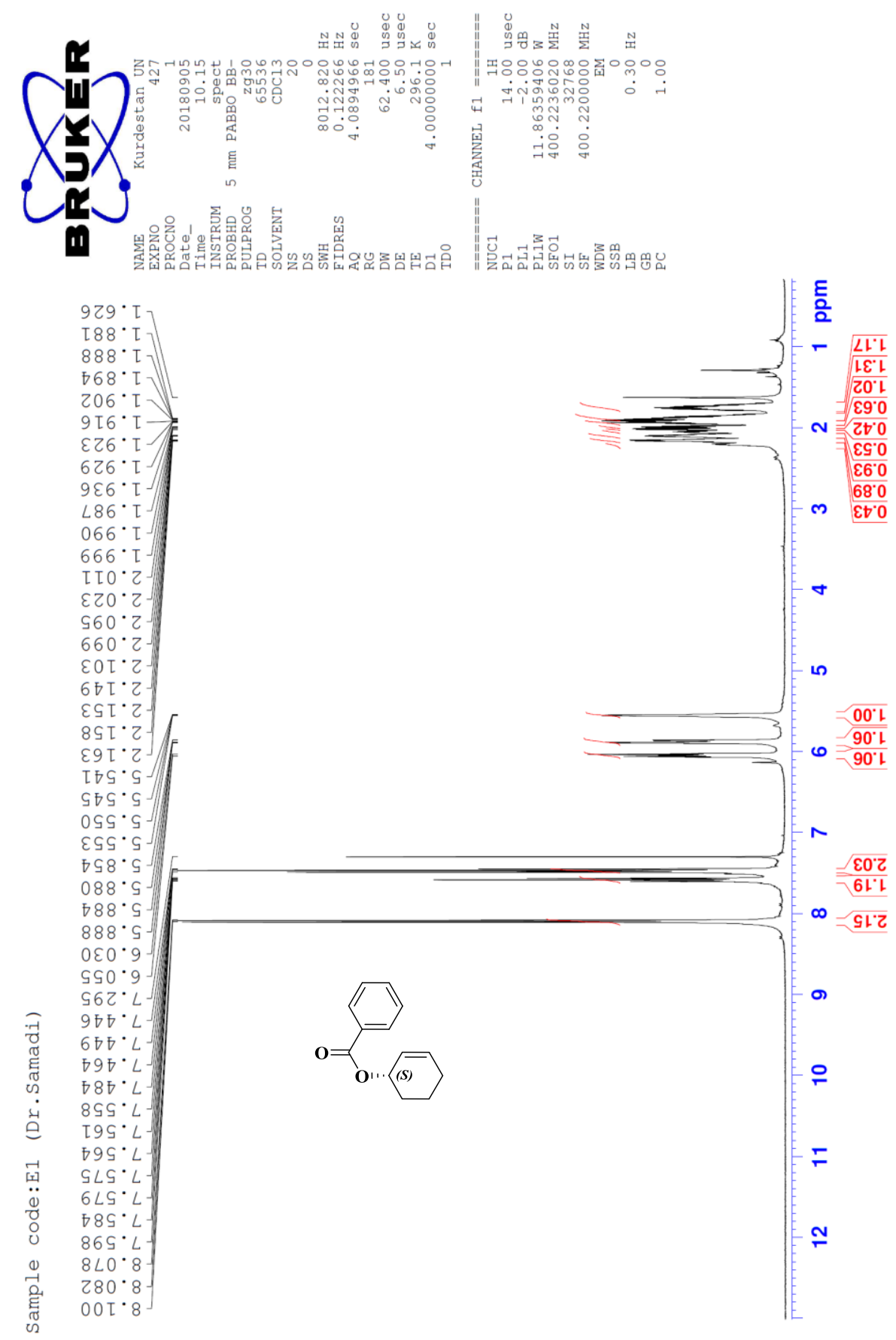

Figure S19: ${ }^{1} \mathrm{H}$ NMR of 8a 

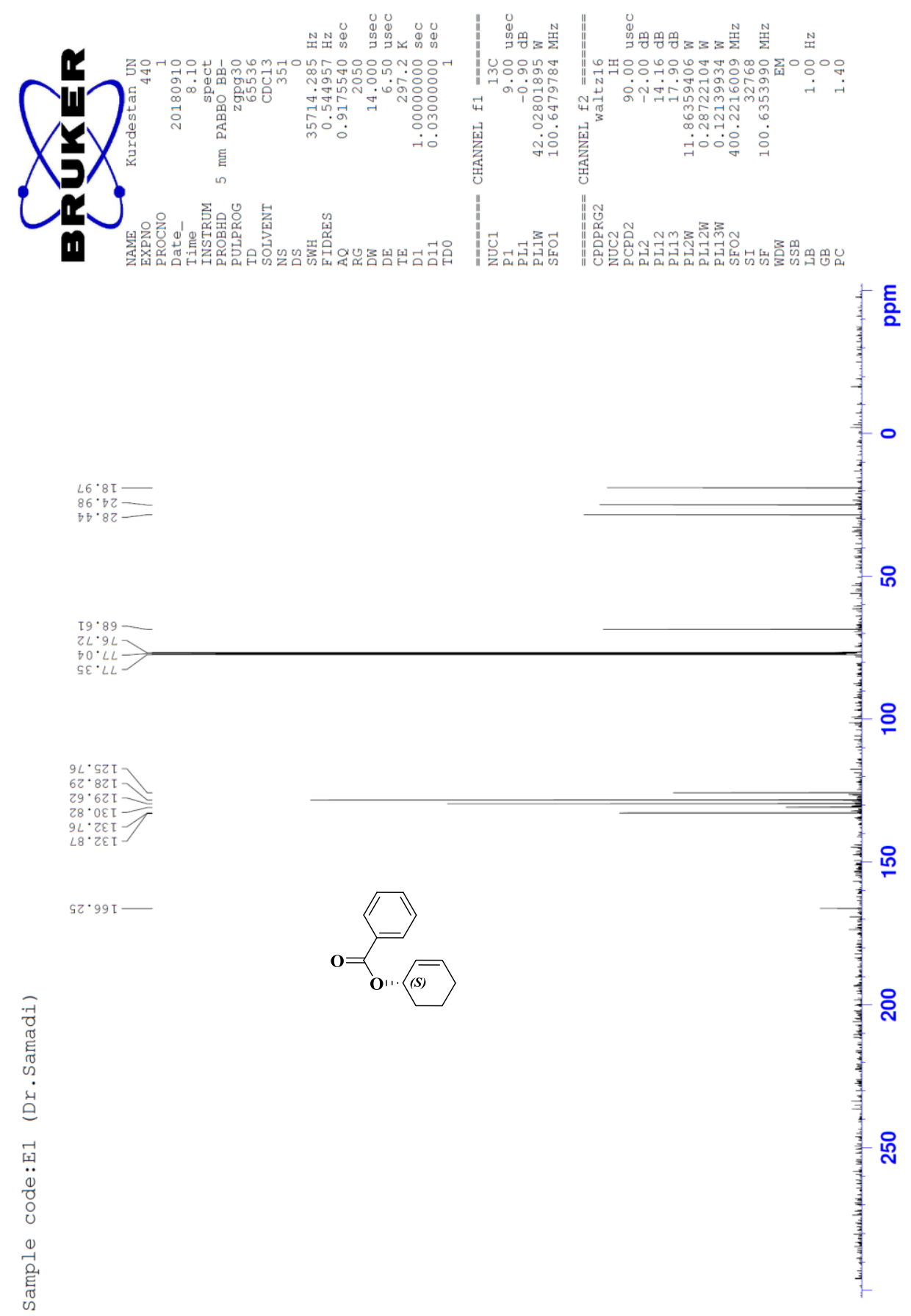

Figure S20: ${ }^{13} \mathrm{CNMR}$ of $\mathbf{8 a}$ 

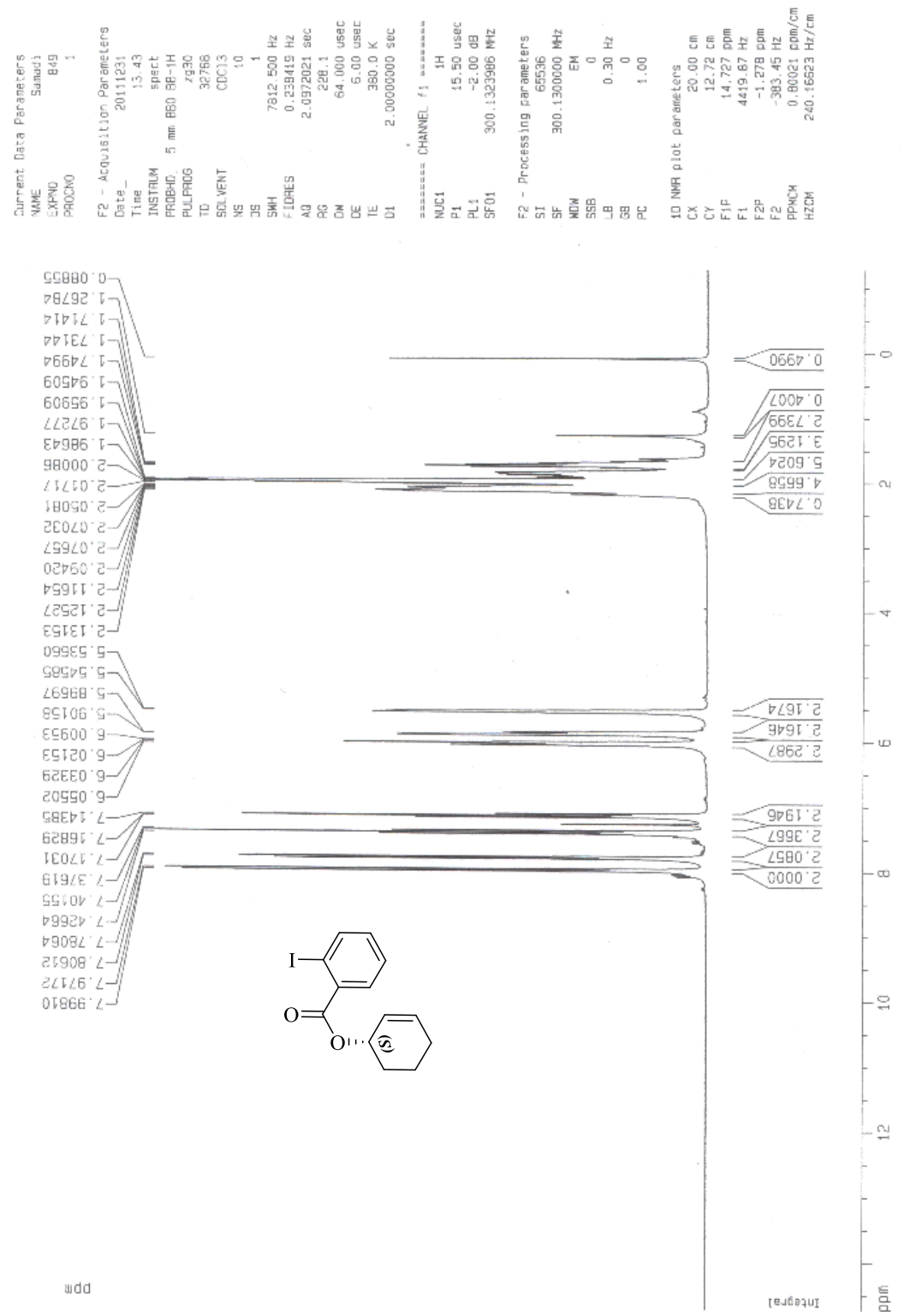

Figure S21: ${ }^{1} \mathrm{H}$ NMR of $\mathbf{8 b}$ 


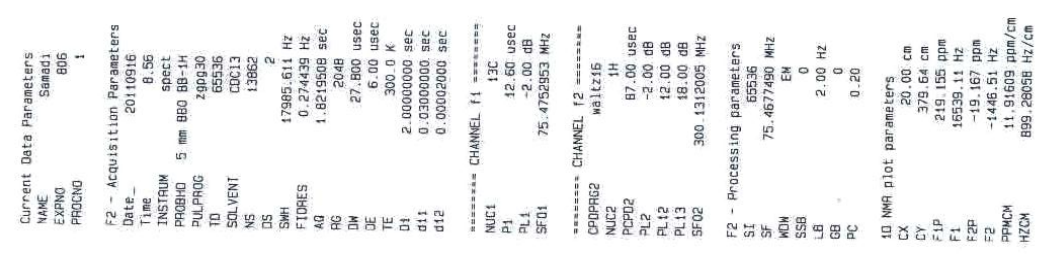

Er8 $81-$

$802 \mathrm{CE}-$

956: $b 5$

เट己:8己-

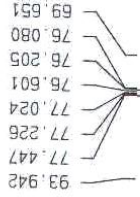

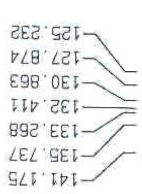

89e 991
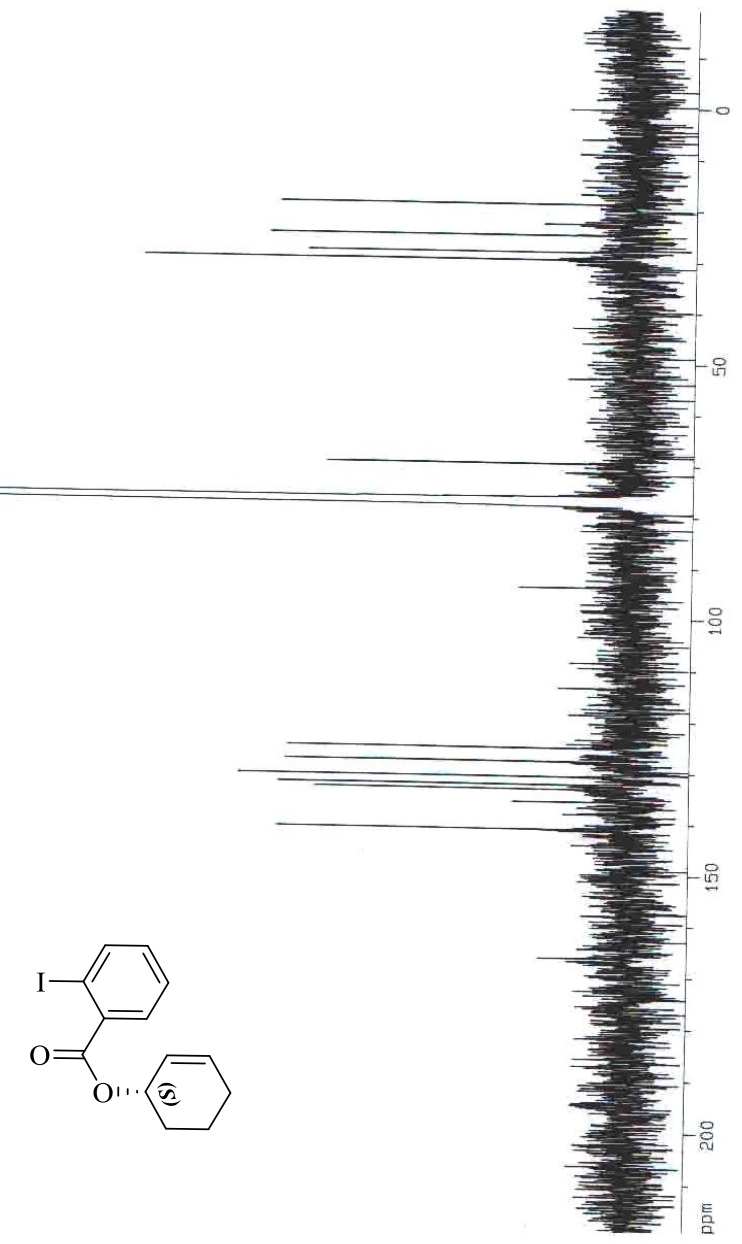

wdo

Figure S22: ${ }^{13} \mathrm{CNMR}$ of $\mathbf{8 b}$ 

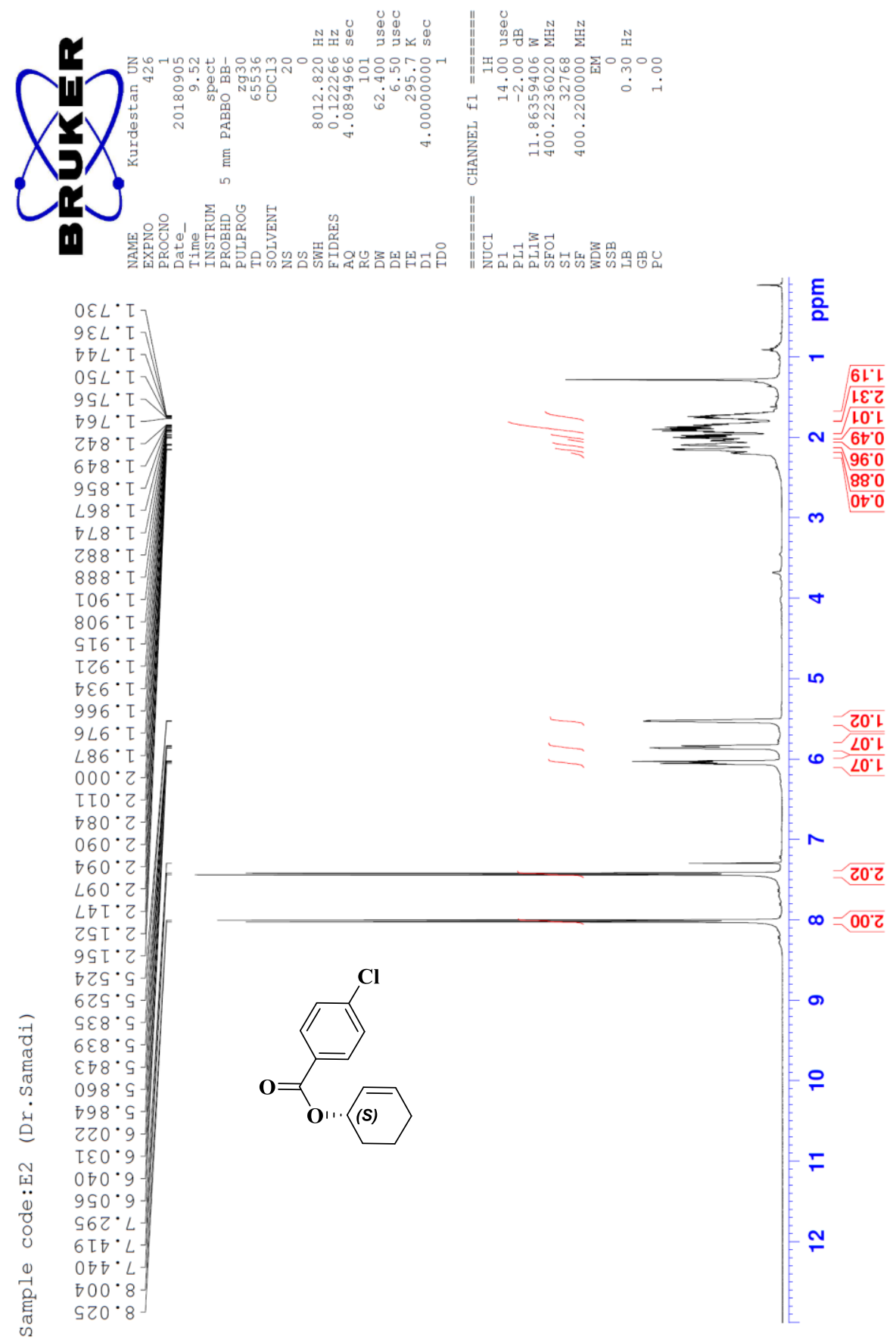

Figure S23: ${ }^{1} \mathrm{H}$ NMR of $\mathbf{8 f}$ 

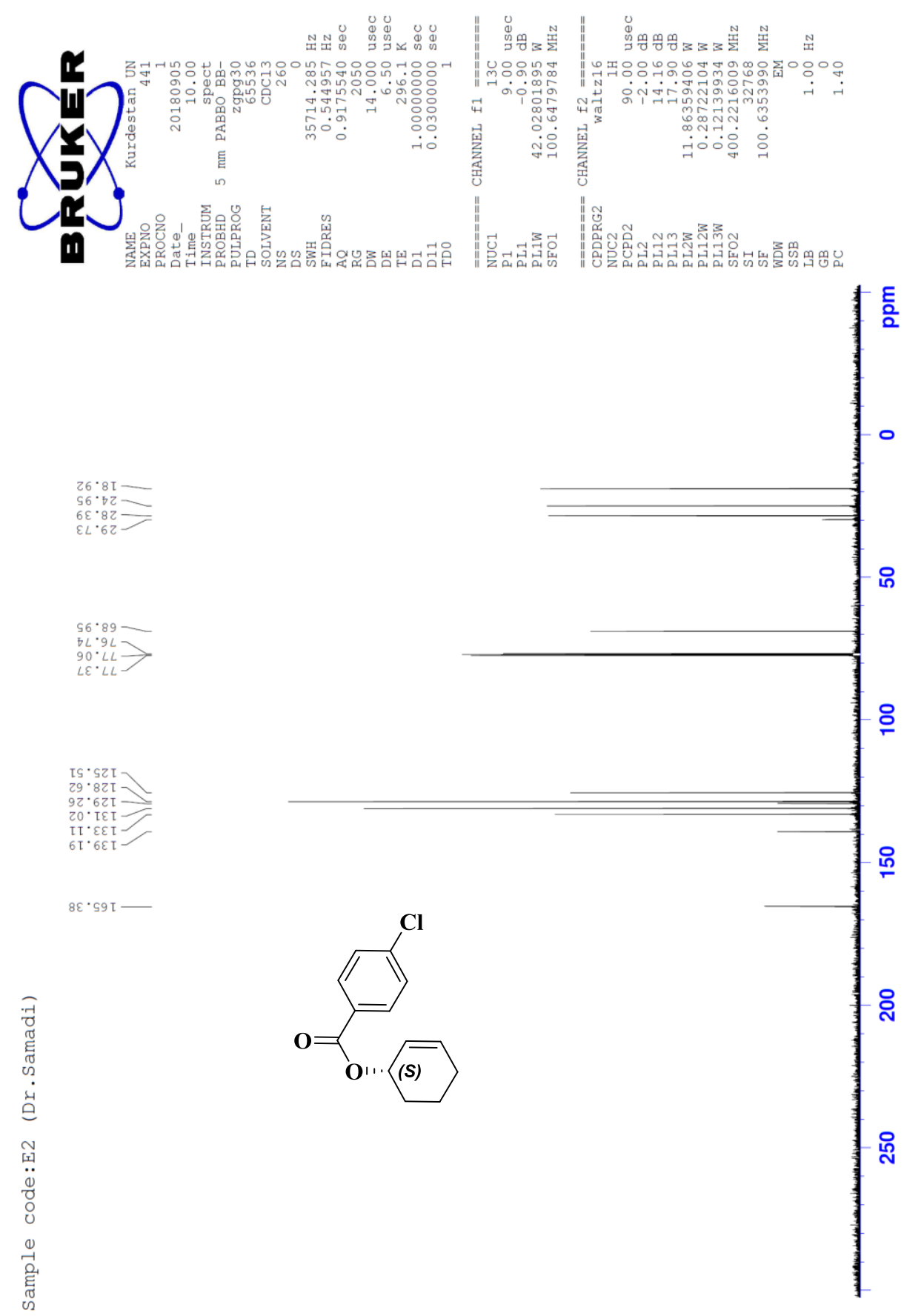

Figure S24: ${ }^{13} \mathrm{C}$ NMR of $8 f$ 


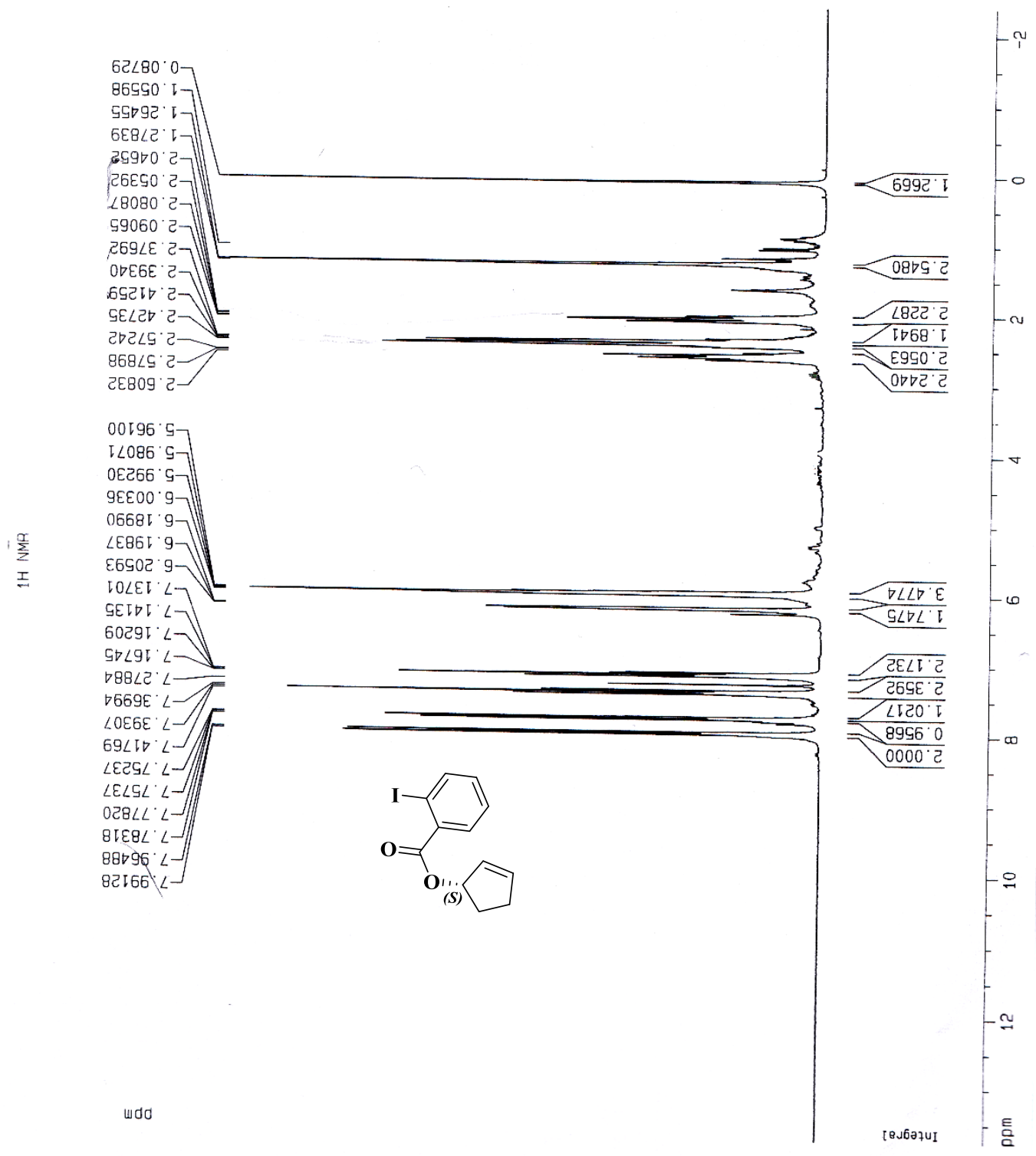

Figure S25: ${ }^{1} \mathrm{H}$ NMR of $9 b$ 


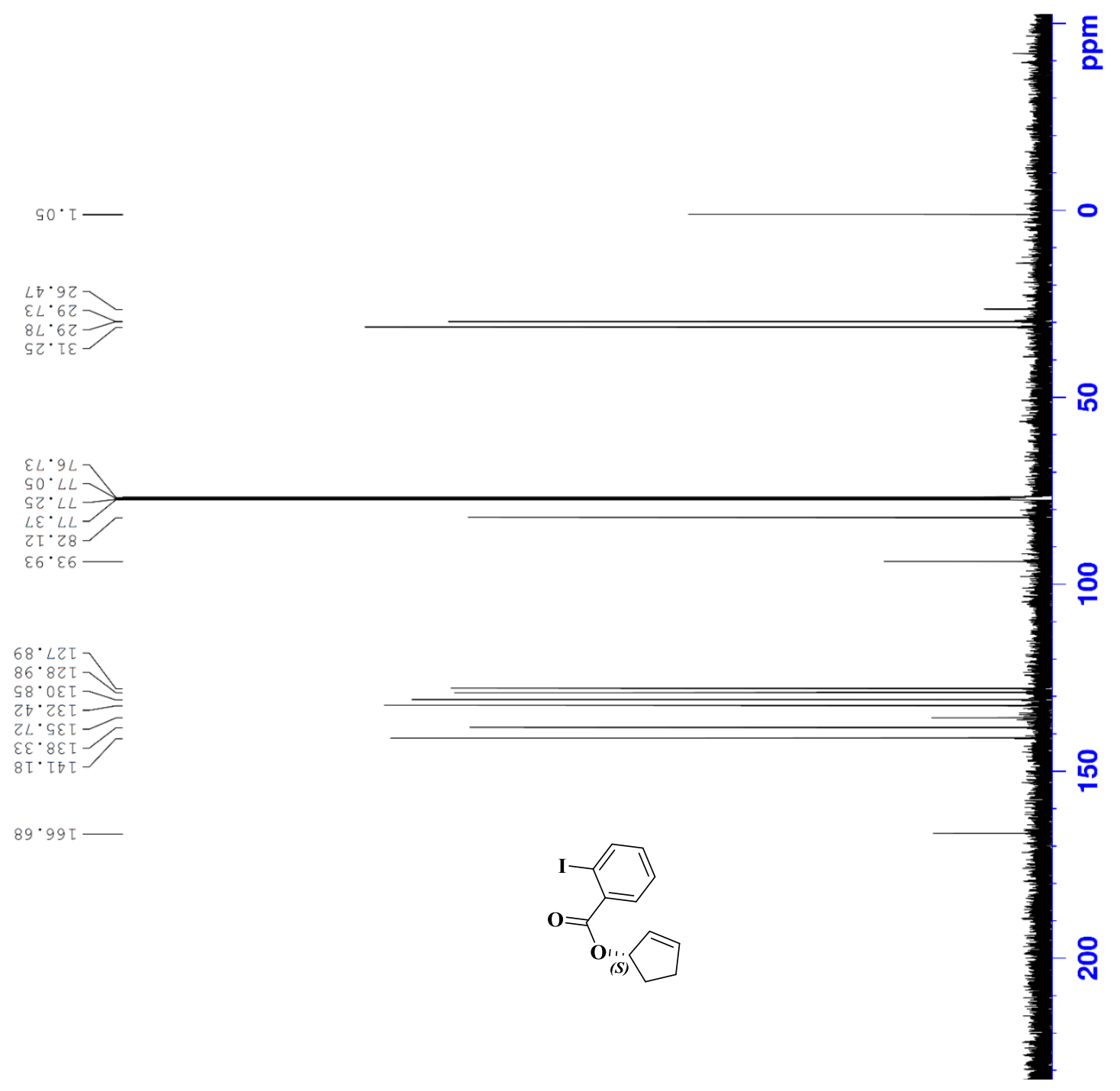

Figure S26: ${ }^{13} \mathrm{CNMR}$ of $9 \mathrm{~b}$ 


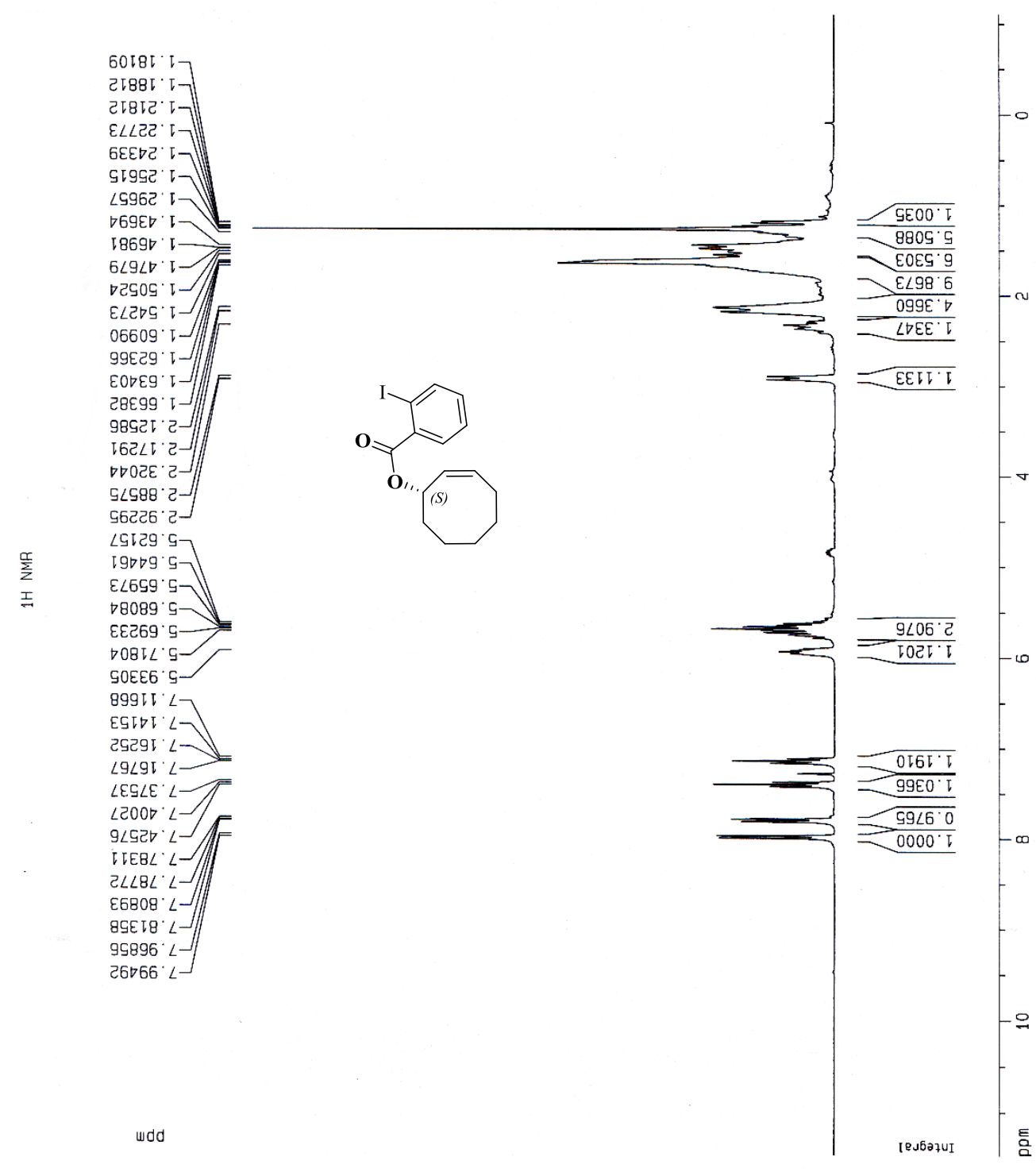

Figure S27: ${ }^{1} \mathrm{H}$ NMR of $\mathbf{1 0 b}$ 


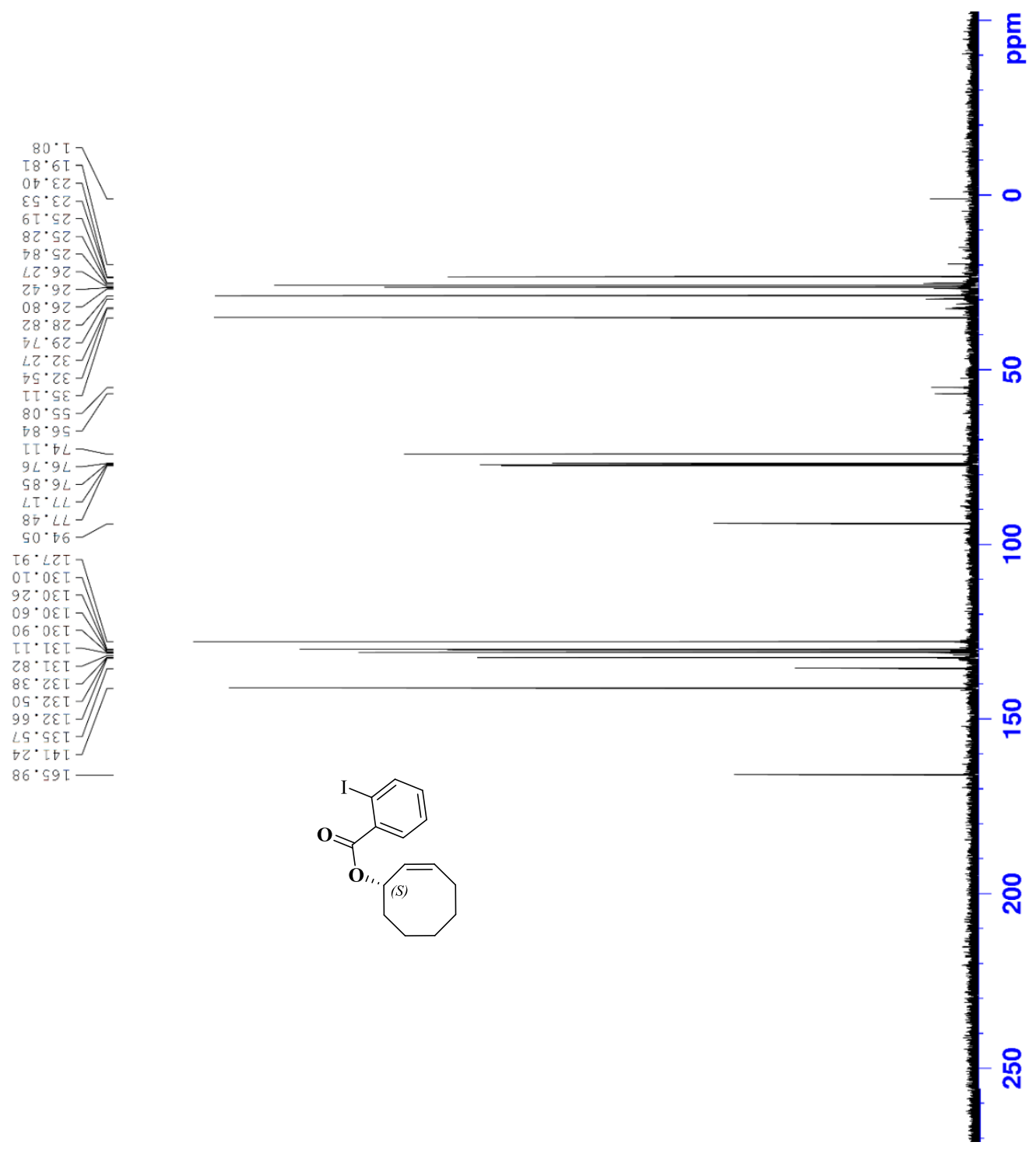

Figure S28: ${ }^{13} \mathrm{CNMR}$ of $\mathbf{1 0 b}$ 

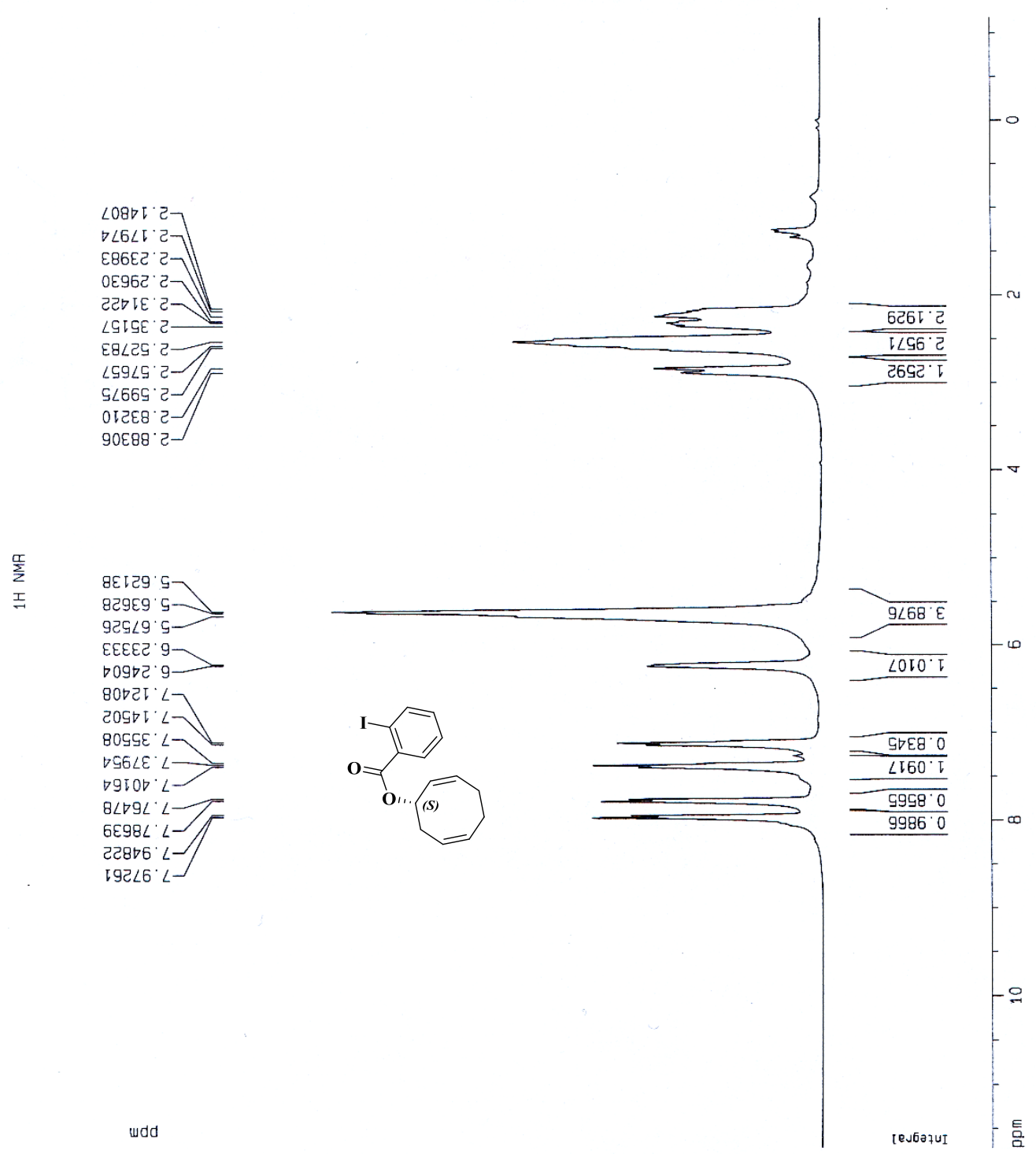

Figure S29: ${ }^{1} \mathrm{H}$ NMR of $\mathbf{1 1 b}$ 


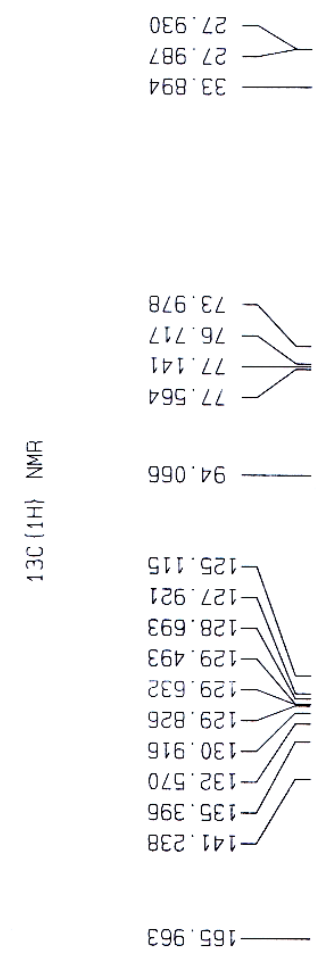

udd

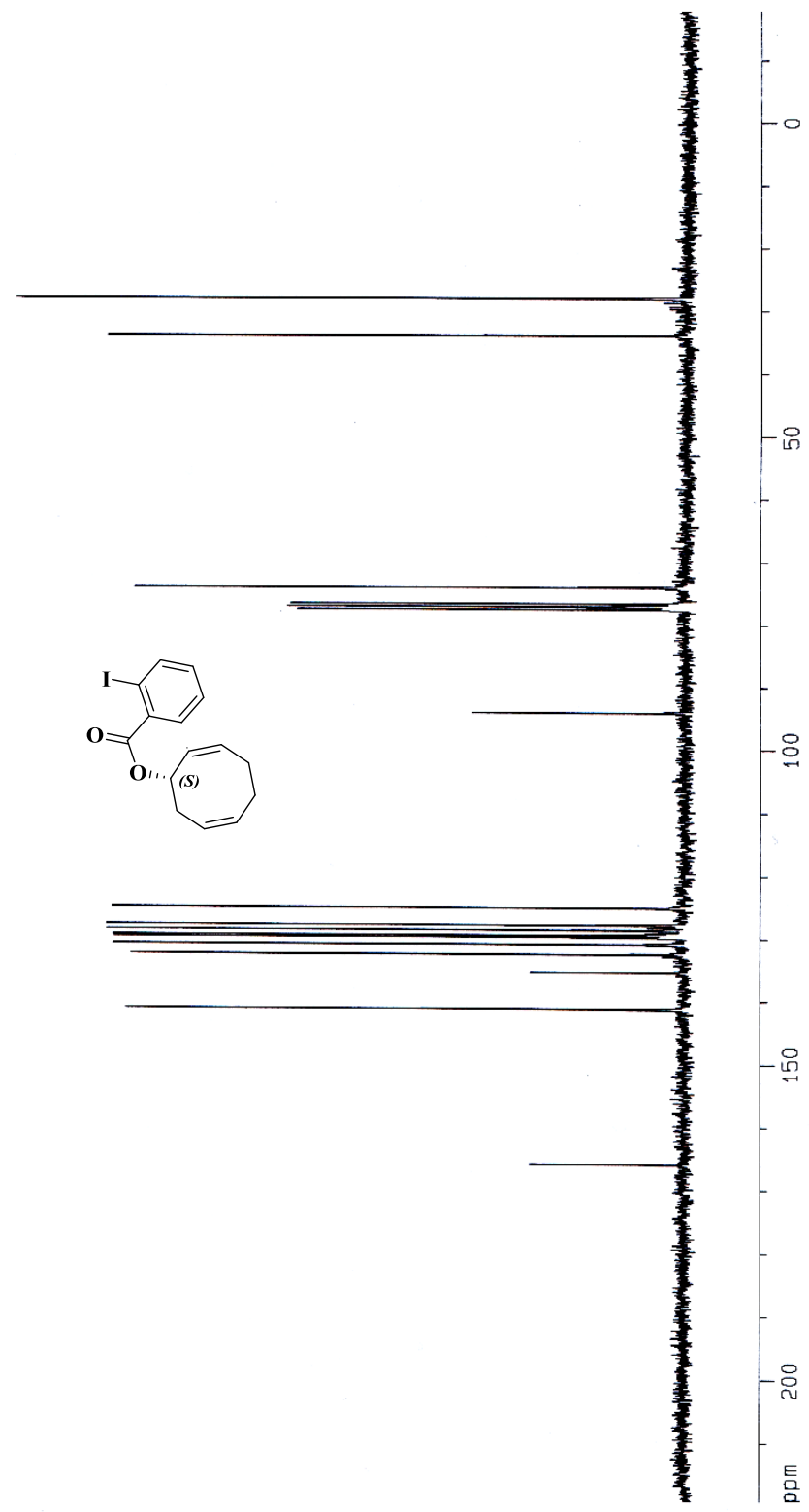

Figure S30: ${ }^{13} \mathrm{CNMR}$ of $\mathbf{1 1 b}$ 


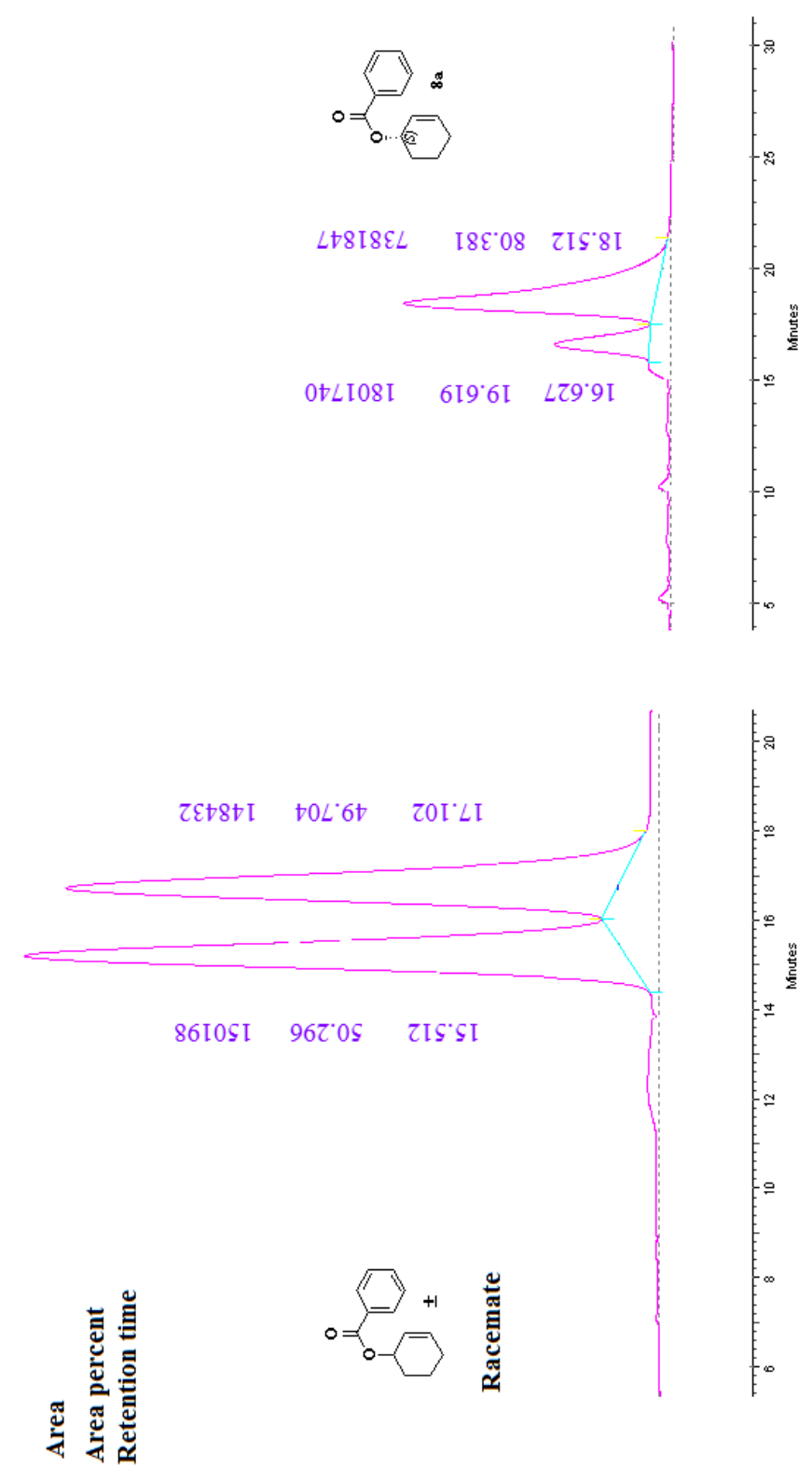

Figure S31: Chromatogram of $\mathbf{8 a}$ 

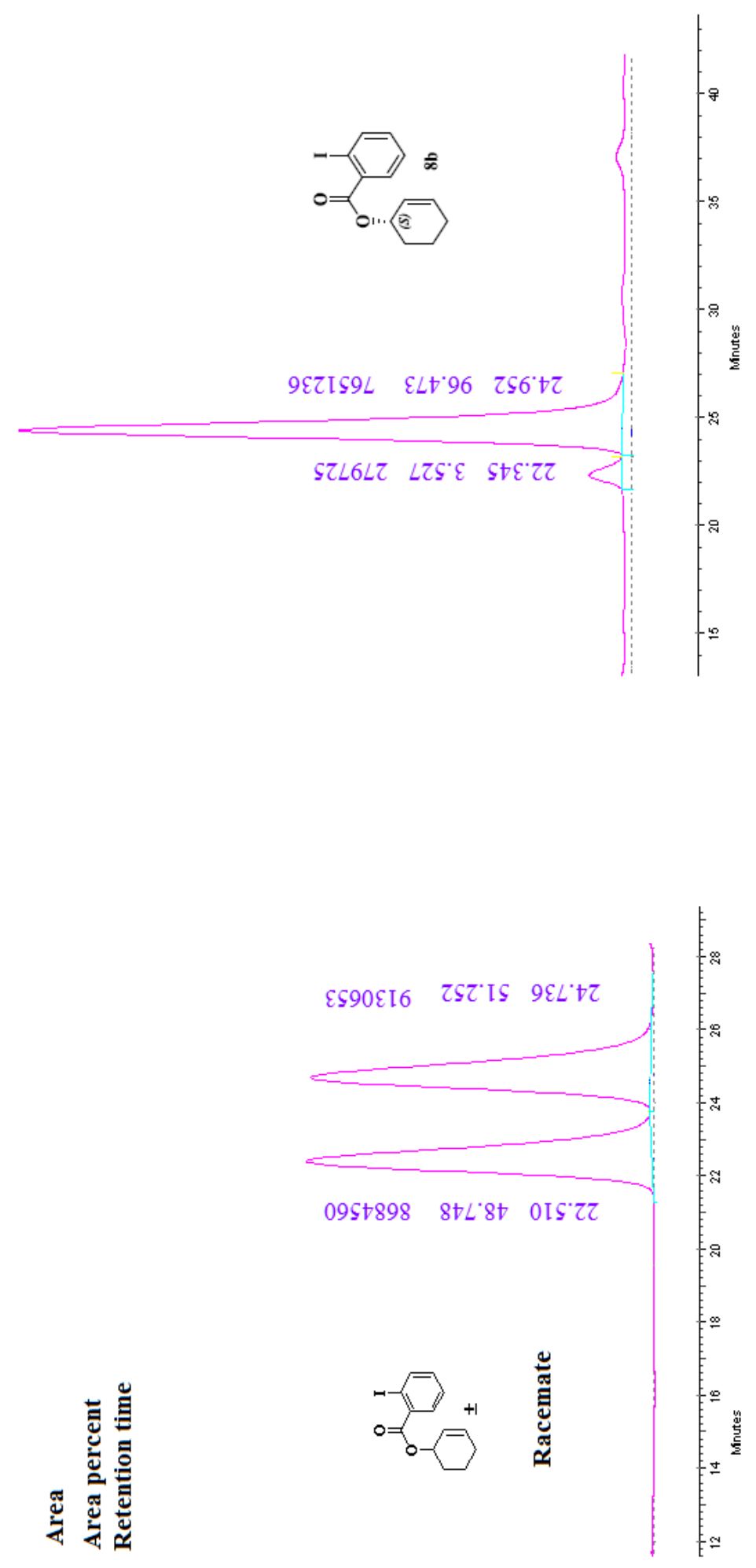

Figure S32: Chromatogram of $\mathbf{8 b}$ 


\section{REFERENCES:}

(1) McKennon, M. J.; Meyers, A. I.; Drauz, K.; Schwarm, M. A convenient reduction of amino acids and their derivatives. J. Org. Chem. 1993, 58, 3568-3571.

(2) Samadi, S.; Ashouri, A.; Ghambarian, M. Use of $\mathrm{CuO}$ encapsulated in mesoporous silica SBA-15 as a recycled catalyst for allylic $\mathrm{C}-\mathrm{H}$ bond oxidation of cyclic olefins at room temperature. $R S C A d v .2017,7$, 19330-19337.

(3) Zhao, D.; Feng, J.; Huo, Q.; Melosh, N.; Fredrickson, G. H.; Chmelka, B. F.; Stucky, G. D. Triblock copolymer syntheses of mesoporous silica with periodic 50 to 300 angstrom pores. Science 1998, 279, 548552.

(4) Samadi, S.; Jadidi, K.; Khanmohammadi, B.; Tavakoli, N. Heterogenization of chiral mono oxazoline ligands by grafting onto mesoporous silica MCM-41 and their application in copper-catalyzed asymmetric allylic oxidation of cyclic olefins. J. Catal. 2016, 340, 344-353.

(5) Andrus, M. B.; Asgari, D. Asymmetric allylic oxidation with biarylbisoxazoline-copper (I) catalysis. Tetrahedron 2000, 56, 5775-5780.

(6) Sadjadi, S.; Samadi, S.; Samadi, M. $\mathrm{Cu}\left(\mathrm{CH}_{3} \mathrm{CN}\right)_{4} \mathrm{PF}_{6}$ immobilized on halloysite as efficient heterogeneous catalyst for oxidation of allylic $\mathrm{C}-\mathrm{H}$ bonds in olefins under mild reaction condition. Res. Chem. Intermed. 2019, 45, 2441-2455.

(7) Samadi, S.; Ashouri, A.; Kamangar, S.; Pourakbari, F. 2-Aminopyrazine-functionalized MCM-41 nanoporous silica as a new efficient heterogeneous ligand for $\mathrm{Cu}$-catalyzed allylic $\mathrm{C}-\mathrm{H}$ bonds oxidation of olefins. Res. Chem. Intermed. 2020, 46, 557-569.

(8) Samadi, S.; Jadidi, K.; Samadi, M.; Ashouri, A.; Notash, B. Designing chiral amido-oxazolines as new chelating ligands devoted to direct $\mathrm{Cu}$-catalyzed oxidation of allylic $\mathrm{C}-\mathrm{H}$ bonds in cyclic olefins. Tetrahedron 2019, 75, 862-867.

(9) Samadi, S.; Jadidi, K.; Notash, B. Chiral bisoxazoline ligands with a biphenyl backbone: development and application in catalytic asymmetric allylic oxidation of cycloolefins. Tetrahedron: Asymmetry 2013, 24, $269-277$. 